\title{
Synthesis and biological evaluation of a Tc-99m- labelled sulfonamide conjugate for in vivo visualization of carbonic anhydrase IX expression in tumor hypoxia
}

Citation for published version (APA):

Akurathi, V., Dubois, L., Lieuwes, N. G., Chitneni, S. K., Cleynhens, B. J., Vullo, D., Supuran, C. T., Verbruggen, A. M., Lambin, P., \& Bormans, G. M. (2010). Synthesis and biological evaluation of a Tc$99 \mathrm{~m}$-labelled sulfonamide conjugate for in vivo visualization of carbonic anhydrase IX expression in tumor hypoxia. Nuclear Medicine and Biology, 37(5), 557-564. https://doi.org/10.1016/j.nucmedbio.2010.02.006

Document status and date:

Published: 01/07/2010

DOI:

10.1016/j.nucmedbio.2010.02.006

Document Version:

Publisher's PDF, also known as Version of record

\section{Document license:}

Taverne

\section{Please check the document version of this publication:}

- A submitted manuscript is the version of the article upon submission and before peer-review. There can be important differences between the submitted version and the official published version of record. People interested in the research are advised to contact the author for the final version of the publication, or visit the DOI to the publisher's website.

- The final author version and the galley proof are versions of the publication after peer review.

- The final published version features the final layout of the paper including the volume, issue and page numbers.

Link to publication

\footnotetext{
General rights rights.

- You may freely distribute the URL identifying the publication in the public portal. please follow below link for the End User Agreement:

www.umlib.nl/taverne-license

Take down policy

If you believe that this document breaches copyright please contact us at:

repository@maastrichtuniversity.nl

providing details and we will investigate your claim.
}

Copyright and moral rights for the publications made accessible in the public portal are retained by the authors and/or other copyright owners and it is a condition of accessing publications that users recognise and abide by the legal requirements associated with these

- Users may download and print one copy of any publication from the public portal for the purpose of private study or research.

- You may not further distribute the material or use it for any profit-making activity or commercial gain

If the publication is distributed under the terms of Article $25 \mathrm{fa}$ of the Dutch Copyright Act, indicated by the "Taverne" license above, 
Anti-Tumour Treatment

\title{
Systematic review and meta-analysis of radiotherapy in various head and neck cancers: Comparing photons, carbon-ions and protons
}

\author{
Bram L.T. Ramaekers ${ }^{\mathrm{a}, *}$, Madelon Pijls-Johannesma ${ }^{\mathrm{a}, \mathrm{e}}$, Manuela A. Joore ${ }^{\mathrm{b}, \mathrm{c}, \mathrm{f}, \mathrm{g}}$, Piet van den Ende ${ }^{\mathrm{a}, \mathrm{e}}$, \\ Johannes A. Langendijk ${ }^{\mathrm{d}, \mathrm{h}}$, Philippe Lambin ${ }^{\mathrm{a}, \mathrm{e}}$, Alfons G.H. Kessels ${ }^{\mathrm{c}, \mathrm{g}, \mathrm{i}}$, Janneke P.C. Grutters ${ }^{\mathrm{b}, \mathrm{f,i}}$ \\ ${ }^{a}$ Department of Radiation Oncology (MAASTRO), GROW, School for Oncology and Developmental Biology, Maastricht University Medical Center, P.O. Box 1588, 6201 BN \\ Maastricht, The Netherlands \\ ${ }^{\mathrm{b}}$ Department of Health Organization, Policy and Economics (HOPE), Maastricht University, P.O. Box 616, 6200 MD Maastricht, The Netherlands \\ ${ }^{\mathrm{c}}$ Department of Clinical Epidemiology and Medical Technology Assessment, Maastricht University Medical Center, P.O. Box 5800, 6202 AZ Maastricht, The Netherlands \\ ${ }^{\mathrm{d}}$ Department of Radiation Oncology, University Medical Center Groningen/University of Groningen, P.O. Box 30001, 9700 RB Groningen, The Netherlands
}

\section{A R T I C L E I N F O}

\section{Article history:}

Received 21 June 2010

Received in revised form 4 August 2010

Accepted 8 August 2010

\section{Keywords:}

Radiotherapy

Photon

IMRT

Particle

Carbon-ion

Proton

Head and neck cancer

Meta-analysis

Systematic review

\begin{abstract}
A B S T R A C T
Purpose: To synthesize and compare available evidence considering the effectiveness of carbon-ion, proton and photon radiotherapy for head and neck cancer.

Methods: A systematic review and meta-analyses were performed to retrieve evidence on tumor control, survival and late treatment toxicity for carbon-ion, proton and the best available photon radiotherapy. Results: In total 86 observational studies (74 photon, 5 carbon-ion and 7 proton) and eight comparative in-silico studies were included. For mucosal malignant melanomas, 5-year survival was significantly higher after carbon-ion therapy compared to conventional photon therapy (44\% versus $25 \%$; $P$-value 0.007). Also, 5-year local control after proton therapy was significantly higher for paranasal and sinonasal cancer compared to intensity modulated photon therapy ( $88 \%$ versus $66 \%$; $P$-value 0.035 ). No other statistically significant differences were observed. Although poorly reported, toxicity tended to be less frequent in carbon-ion and proton studies compared to photons.

In-silico studies showed a lower dose to the organs at risk, independently of the tumor site.

Conclusions: For carbon-ion therapy, the increased survival in mucosal malignant melanomas might suggest an advantage in treating relatively radio-resistant tumors. Except for paranasal and sinonasal cancer, survival and tumor control for proton therapy were generally similar to the best available photon radiotherapy. In agreement with included in-silico studies, limited available clinical data indicates that toxicity tends to be lower for proton compared to photon radiotherapy.

Since the overall quantity and quality of data regarding carbon-ion and proton therapy is poor, we recommend the construction of an international particle therapy register to facilitate definitive comparisons.
\end{abstract} (c) 2010 Elsevier Ltd. All rights reserved.

\section{Introduction}

Head and neck cancer (HNC) covers a heterogeneous group of cancers, which includes paranasal and sinonasal cancer and cancer of the salivary gland, lip, oral cavity, pharynx and larynx. When

\footnotetext{
* Corresponding author. Tel.: +31 (0) 884455 798; fax: +31 (0) 884455667.

E-mail addresses: bram.ramaekers@maastro.nl (B.L.T. Ramaekers), madelon. pijls@maastro.nl (M. Pijls-Johannesma),m.joore@mumc.nl (M.A. Joore), piet.vande nende@maastro.nl (P. van den Ende), j.a.langendijk@rt.umcg.nl (J.A. Langendijk), philippe.lambin@maastro.nl (P. Lambin), fons.kessels@mumc.nl (A.G.H. Kessels), j.grutters@beoz.unimaas.nl (J.P.C. Grutters).

e Tel.: +31 (0) 884455 666; fax: +31 (0) 884455667 .

f Tel.: +31 (0) 43388 2907; fax: +31 (0) 433670960

g Tel.: +31 (0) 43387 5559; fax: +31 (0) 433874419 .

h Tel.: +31 (0) 50361 5532; fax: +31 (0) 503613672

i These authors contributed equally to this work.
}

considering cancer of the oral cavity, pharynx and larynx in Europe, the annual incidence is approximately 147,500 . This represents $4.6 \%$ of all cancer cases, accounting for 63,400 deaths. ${ }^{1}$

Treatment options for HNC consist of radiotherapy, surgery, chemotherapy or a combination of these modalities. There is a growing body of evidence suggesting that more aggressive treatment regimes, such as altered fractionation schedules for radiotherapy or (concomitant) chemoradiation improve tumor control and survival. ${ }^{2-4}$ Recent meta-analyses showed absolute improvements in 5-year survival of $3 \%$ for altered fractionation versus conventional fractionation and of $5 \%$ for chemotherapy versus no chemotherapy. ${ }^{3,4}$ However, mainly due to the close proximity of critical organs and the often large irradiation fields, the improved outcomes in these aggressive treatment regimes come at the cost of increased treatment toxicity. Late toxicities (including xerostomia and dysphagia) affect a substantial proportion of HNC patients 
and negatively affects patients' functional outcomes and quality of life. $^{5-9}$

Particle therapy using carbon-ions or protons is currently gaining importance worldwide. ${ }^{10}$ Compared with photons, the indepth dose distribution of particles allows a more accurate dose administration, resulting in an increased therapeutic ratio. Based on these physical characteristics, it is supposed that less normal tissue will be irradiated compared with photon radiation, presumably resulting in less treatment related toxicity. ${ }^{11,12}$ On the other hand, the increased therapeutic ratio possibly permits dose escalation to the tumor, resulting in a higher tumor control probability. Next to these physical advantages, carbon-ion radiotherapy comprises an increased radiobiological efficacy, especially in the Bragg peak. Hence, to decrease treatment related toxicity and potentially further improve outcome, particle therapy could be a valuable technology in the treatment of HNC. Nevertheless, several reviews indicated that based on clinical evidence it remains unclear, mainly because of the absence of randomized trials, whether particle therapy is superior over radiotherapy with photons in HNC. ${ }^{13-20}$ This makes it difficult to decide whether particle therapy should be implemented as a (routine) treatment in clinical practice. ${ }^{21}$ However, decisions need to be made. In addition to the available clinical evidence, comparative in-silico studies, which analyze computerpredicted dose parameters in radiotherapy treatment planning for different radiation techniques, offer an alternative approach to estimate the potential gain of particle therapy. ${ }^{20,22}$ Our aim was therefore to synthesize all available evidence, from clinical studies as well as comparative in-silico studies. This resulted in the following objectives (1) to review and synthesize available clinical evidence considering the effectiveness (i.e. tumor control, survival and late treatment toxicity) of carbon-ion and proton radiotherapy compared with the best available photon radiation in patients receiving radiotherapy treatment for $\mathrm{HNC}$ and, (2) to review available comparative in-silico studies comparing carbon-ion and proton radiotherapy with photon therapy in HNC.

\section{Methods}

\section{Search strategy and selection criteria}

Systematic literature searches were conducted to identify available clinical particle and photon studies. A first search query was constructed to identify studies using carbon-ions or protons in HNC. Included photon studies were identified using a second (intensity modulated radiotherapy) and third (conventional radiotherapy) search query. The PICO (patient, intervention, comparison and outcome) framework ${ }^{23}$ was used to structure all three search queries in Pubmed. MeSH terms as well as free text words were used. The keywords were 'head and neck cancer' AND ('proton radiotherapy' OR 'carbon-ion radiotherapy' OR 'intensity modulated radiotherapy' OR 'radiotherapy') AND ('survival' OR 'adverse effects'). The full search strategy is reported in Appendix 1.

All search queries were updated until February 2010. In addition, manual searches of reference lists were performed to complement all three search queries. For particle therapy, supplementary manual searches of conference proceedings were performed.

Clinical studies were included if they were published after 1990, written in English, examined carbon-ions, protons or photons, examined treatment of primary tumors, examined radical treatment (defined as a treatment with the intent to obtain loco-regional disease control) and had a patient sample $\geqslant 10$. For photon therapy, if available, only studies using intensity modulated radiotherapy (IMRT) were included. If no IMRT studies were available, studies administering conventional photon therapy were included. Further, photon studies were only included if tumor control or survival data was reported. In order to collect all available evidence on particle therapy, particle studies were also included if they report toxicity data only. Occasionally data were reported in multiple publications. In case of overlap in data and if both studies reported the required data, only the study with the largest sample size was included.

To identify in-silico studies comparing particle therapy and photon therapy in HNC, a fourth search strategy was constructed. This search query was structured as described above for clinical studies. The search query was equal to the first search query, except for the keyword 'radiotherapy planning' instead of ('survival' OR 'adverse effects') (Appendix 1).

In-silico studies were included if they were published after 1990, written in English, performed a direct comparison of particle therapy (carbon-ions or protons) with photon therapy, examined treatment of primary tumors, reported dose to the organs at risk and had a patient sample $\geqslant 5$.

\section{Data extraction}

General characteristics were extracted from clinical studies: first author, year of publication, treatment type, sample size, dose per fraction, number of fractions, total treatment dose, study population (age, tumor stage, location and histology, percentage of operated patients, and percentage patients of receiving chemotherapy), late treatment toxicity, local control, disease free survival and overall survival outcomes at 2- to 5-year. Since HNC represents a heterogeneous patient group with different treatment modalities and prognosis, the comparisons of clinical studies were categorized according to location or histology. The subgroups were nasopharyngeal cancer, oropharyngeal cancer, paranasal and sinonasal cancer, mucosal malignant melanomas and adenoid cystic carcinomas. Because radiotherapy toxicity is location specific, different types of toxicities were examined for different subgroups. Xerostomia and dysphagia were considered in nasopharyngeal and oropharyngeal cancer, visual toxicity in paranasal and sinonasal cancer, visual, skin and mucosal toxicity in mucosal malignant melanomas and all reported toxicity in adenoid cystic carcinomas. Toxicity data were extracted per type and grade independently of the classification system.

The following characteristics were extracted for included in-silico studies: first author, year of publication, treatment types, sample size, tumor location and/or histology, dose parameters of target volume (coverage, conformity index ${ }^{24}$ and inhomogeneity) and dose to organs at risk (dose to the optic nerves for paranasal sinus carcinomas and for all other sites dose to the parotid glands and pharyngeal constrictors). These organs at risk were selected since they are associated with visual impairment, ${ }^{25}$ xerostomia ${ }^{26}$ and dysphagia. ${ }^{27,28}$

All data were independently extracted by two reviewers (BR and MPJ), if necessary data were extracted from figures. Discrepancies were solved in consensus meetings with all authors.

\section{Statistical analysis}

If tumor control or survival outcomes were available per subgroup for at least two comparators, data from clinical studies were pooled for the longest available follow-up period. Pooling was performed by means of a random effect meta-regression analysis. If corresponding standard errors (se) were not reported in included studies, we calculated them using the standard method for proportions. ${ }^{29}$ If patients were censored, we used the Peto method. ${ }^{30,31}$ In case the number of censored patients was not reported, we assumed the maximum percentage of censored patients reported in the included studies in the subgroup concerned. 
Through relating the outcomes (e.g. survival) to potentially confounding variables (e.g. differences between the included studies in the percentage of patients receiving chemotherapy) in the meta-regression analyses, we explored the effect of these covariates on the outcome. ${ }^{32}$ We did this by firstly calculating the overall mean for these covariates among all included studies in the subgroup concerned. Secondly, we calculated for each study separately how much the covariate deviated from the overall mean. Finally, this deviation from the overall mean was included in the meta-regression model as an independent covariate. This was done separately for each subgroup for the following covariates: the proportion of patients having T4 tumors, N3 tumors, stage IV tumors, the proportion of patients receiving chemotherapy, the proportion of operated patients and publication year. Only covariates which significantly influenced the outcomes were included in the final meta-regression models.

For comparative in-silico studies, results were reviewed only and no statistical analyses were performed.

All analyses were performed in STATA 9.1 and a $P$-value $\leqslant 0.05$ was considered statistically significant. Further, this meta-analysis was performed according to proposed guidelines. ${ }^{33}$

\section{Results}

The three search strategies considering clinical studies identified 86 eligible observational studies: five studies using carbonion therapy, seven studies using proton therapy and 74 studies using photon therapy. The fourth search strategy identified eight eligible comparative in-silico studies (Appendix 2). Included and excluded particle studies and in-silico studies were reported in Appendix 3. The characteristics of the clinical studies pooled in the meta-analyses were reported in Appendix 4. Further, results of the meta-analyses are presented in Fig. 1 and Table 1 . The eight in-silico studies were reviewed separately from the clinical studies.

\section{Head and neck cancer}

Three studies on particle therapy (two carbon-ion and one proton $)^{34-36}$ and eight studies on IMRT ${ }^{37-44}$ reported on a mixed group (multiple sub-sites) of HNC patients. Local control (LC) rates at 2and 5 year were $80-85 \%$ and $60-70 \%$ for carbon-ion therapy, $87 \%$ and $74 \%$ for proton therapy and 2-year LC ranged between $76 \%$ and $100 \%$ for IMRT. Disease free survival (DFS) estimates at 2and 5 -year were $56 \%$ and $29 \%$ for proton therapy and $81-90 \%$ at 2-year for IMRT. Overall survival (OS) at 2- and 5-year were respectively $74 \%$ and $33-48 \%$ for carbon-ion therapy; $69 \%$ and $44 \%$ for proton therapy and $83-90 \%$ at 2-year for IMRT. Due to heterogeneity within and between these studies, these results deemed largely not comparable and outcomes were therefore not pooled in a meta-analysis.

\section{Nasopharyngeal carcinoma}

One proton study ${ }^{45}$ and 14 IMRT studies ${ }^{46-59}$ reported results for nasopharyngeal carcinomas. Estimates of 3-year LC were $92 \%$ for proton therapy and 95\% for IMRT. Pooled 3-year OS estimates were $74 \%$ for proton therapy and $90 \%$ for IMRT. Both LC and OS were not statistically significantly different ( $P$-values 0.780 and $0.298)$.

The percentage of T4 patients in the proton study was approximately twice as high as in most IMRT studies (Appendix 4). Nevertheless, this covariate had no statistically significant influence on the outcome. The year of publication had a statistically significant ( $P$-value 0.040 ) influence on the 3-year LC favoring older studies. The corrected estimates were similar to the uncorrected estimate for 3-year LC for both IMRT (both estimates were 95\%) and proton therapy (decreased from $92 \%$ to $90 \%$ ). As a result, differences in 3-year LC between IMRT and protons remained not statistically significant. The remaining covariates considering disease stage, the proportion of patients receiving chemotherapy or surgery were not statistically significant.

For proton therapy no late xerostomia or dysphagia data were reported, hence it was not possible to perform comparisons considering late treatment related toxicity.

\section{Oropharyngeal carcinoma}

One proton study ${ }^{60}$ and 10 IMRT studies ${ }^{61-70}$ reported results for oropharyngeal carcinomas. Estimates of 2- and 5-year LC were $96 \%$ and $88 \%$ for proton therapy and for IMRT pooled 2 -year LC was $95 \%$. For DFS, 2- and 5-year rates were $81 \%$ and $65 \%$ for proton therapy, pooled 2-year DFS for IMRT was $87 \%$. Both 2 -year LC and DFS were not statistically significantly different ( $P$-values 0.782 and 0.570 ).

No statistically significant covariates were observed.

For proton therapy no late xerostomia or dysphagia data were reported, hence it was not possible to perform comparisons considering late treatment related toxicity.

\section{Paranasal and sinonasal carcinoma}

One carbon-ion study ${ }^{35}$ two proton studies ${ }^{71,72}$ and two IMRT studies ${ }^{73,74}$ reported results for paranasal or sinonasal carcinoma. The pooled estimates of 5 -year LC were $49 \%$ for carbon-ion therapy, $88 \%$ for proton therapy and $66 \%$ for IMRT. Differences in 5-year LC between proton therapy and IMRT were statistically significant ( $P$-value 0.035$)$. Five-year DFS was $61 \%$ for protons and $54 \%$ for IMRT, while 5-year OS was $71 \%$ and $52 \%$ respectively. Both DFS and $\mathrm{OS}$ were not statistically significantly different ( $P$-values 0.682 and 0.323 ).

It was not possible to include the percentage of patient with T4, $\mathrm{N} 3$ or stage IV tumors as covariates in the meta-analyses since none of the included studies reported the number of stage IV tumors and the number of T4 tumors or N3 tumors were only reported in the two photon studies (Appendix 4). None of the other covariates (including the percentage of operated patients) had a statistically significant influence on the outcome.

One proton study reported that no late visual toxicity of RTOG grade 3 or higher was observed. ${ }^{71}$ However, another study considering visual outcomes after combined photon/proton therapy reported LENT/CTC v2.0 visual toxicity of grades 1,2 and 3 of respectively $14 \%, 17 \%$ and $6 \% .{ }^{75}$ For IMRT, one study reported CTC v2.0 grade 3 visual toxicity in $9 \%$ of the patients, of which four patients (6\%) had pre-treatment visual impairment. ${ }^{74}$

\section{Mucosal malignant melanoma}

For the treatment of mucosal malignant melanomas, 5-year OS was reported in two carbon-ion studies ${ }^{34,76}$ and 18 studies administering conventional radiotherapy. ${ }^{77-94}$ Analyses showed a 5-year OS of $44 \%$ for carbon-ion radiotherapy, this was statistically significantly higher than the pooled estimate of $25 \%$ for conventional photon radiotherapy ( $P$-value 0.007$)$.

The percentage of operated patients as well as the percentage of patients with disease stage III could not be incorporated as potentially confounding variables since none of the studies on carbonion therapy reported these data (Appendix 4). None of the other covariates were statistically significant.

For carbon-ion therapy one study observed late RTOG grade 2 skin toxicity in 3\%, another $3 \%$ had grade 2 mucosal toxicity and the remaining patients had grades $0-1$ toxicity. ${ }^{95}$ No photon 

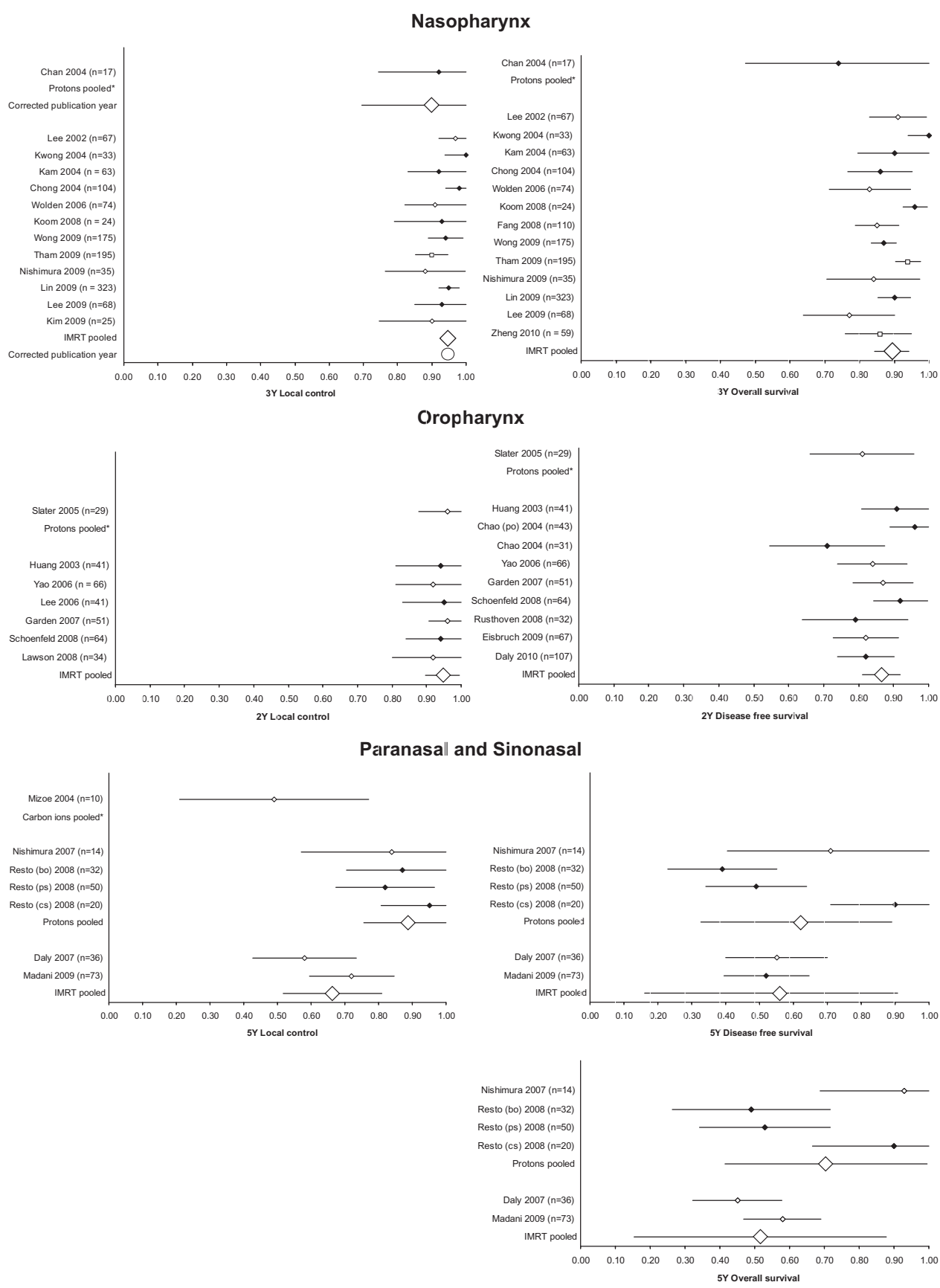

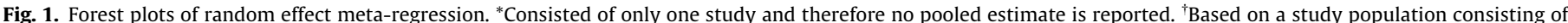

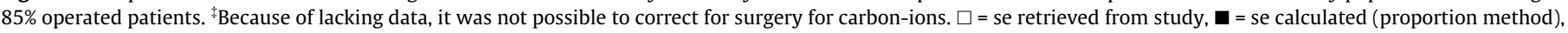

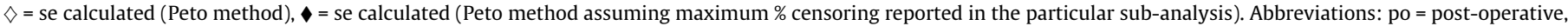
bo $=$ biopsy only, ps = partial surgery, cs = complete surgery, and ct = chemotherapy.

studies reported skin or mucosal toxicity with accompanying grades. One study reported grades 3-4 visual toxicity in two (8\%) patients (one dry eye syndrome and one optic nerve toxicity resulting in decreased visual acuity) after photon radiotherapy. ${ }^{83}$ For carbon-ion therapy no visual toxicity data were reported, hence it was not possible to perform comparisons considering late treatment related visual toxicity.

\section{Adenoid cystic carcinoma}

For adenoid cystic carcinomas (ACC), one non-randomized comparative study which compared carbon-ion therapy $(n=29)$ with photon radiation $(n=34)$ showed no statistically significant differ- ences. ${ }^{96}$ Further, two carbon-ion studies (including updated data of the comparative study), ${ }^{34,97}$ one proton study ${ }^{98}$ and 22 conventional photon studies ${ }^{99-120}$ reported results for adenoid cystic carcinomas.

Meta-analyses resulted in a pooled 5-year LC of $69 \%$ for carbonion therapy, 93\% for proton therapy and $75 \%$ for conventional photon therapy. Pooled 5-year estimates for OS were $70 \%$ for carbon-ion therapy, 77\% for proton therapy and 73\% for photon therapy. No statistically significant differences were observed between carbon-ion therapy, proton therapy and conventional photon therapy for 5-year LC and OS (see Table 1 for $P$-values).

The percentage of operated patients had a statistically significant influence on OS ( $P$-value 0.043$)$ favoring studies with higher proportions of operated patients. Therefore 5-year OS estimates 

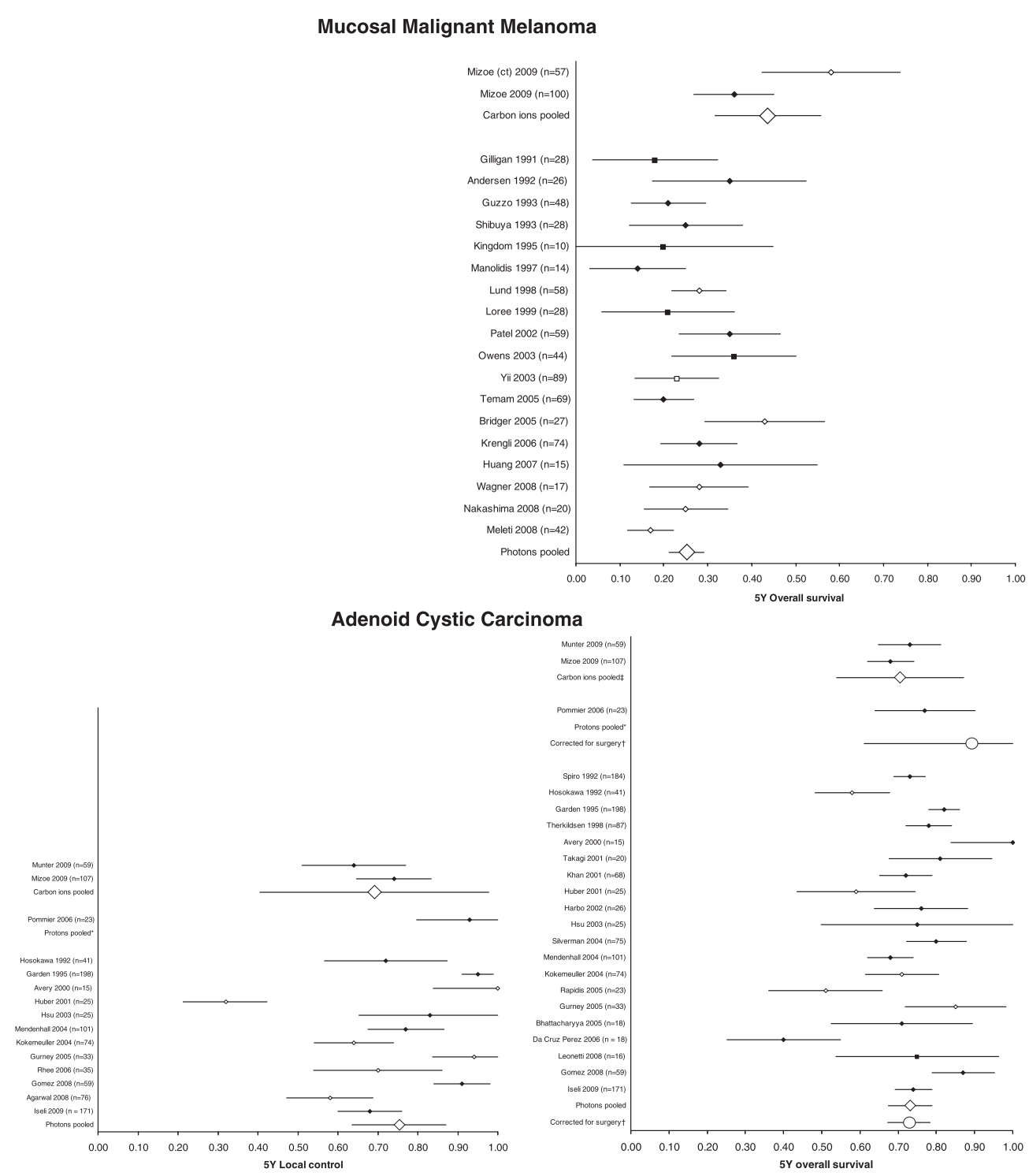

Fig. 1 (continued)

were corrected for this covariate. Due to lacking data, this was not possible for carbon-ion therapy (Appendix 4). The corrected estimate was similar to the uncorrected estimate for 5-year OS for photon therapy (both $73 \%$ ), but for proton therapy the corrected estimate increased from $77 \%$ to $89 \%$. After correcting 5 -year OS, the differences between IMRT and protons remained not statistically significant. The covariates considering disease stage and T4 tumors were not reported in the particle studies and were therefore not included in the analyses. The remaining covariates had no statistically significant influence on the outcome.

For carbon-ion radiotherapy, late CTC v3.0 grades $1-2$ toxicity was observed in $63 \%$ of the patients and no toxicity of grade 3 or higher was reported. ${ }^{97}$ Reported RTOG late grades $1-2$ toxicity in photon studies was $64 \%$ and $84 \%^{104,117}$ and ranged between $4 \%$ and $11 \%$ for grade 3 and higher toxicity. ${ }^{104,109,114,117}$

\section{Comparative in-silico studies}

Eight comparative in-silico studies were included, one ${ }^{121}$ comparing carbon-ion therapy and photon therapy and seven ${ }^{122-128}$ comparing proton therapy and photon therapy.
One in-silico study suggested that for paranasal sinus tumors, carbon-ion therapy has the ability to statistically significantly decrease the dose to the contralateral optic nerve. ${ }^{121}$ However, due to unknown differences in relative biological effectiveness for carbon-ion therapy, it is yet unclear how these differences in dose will translate into clinically relevant outcomes. Also, for proton therapy one in-silico study reported a lower dose to the optic nerves compared with IMRT (Table 2). ${ }^{124}$ No information was provided onto what extent this reduced dose would reduce the probability of visual impairment.

For nasopharyngeal, oropharyngeal, hypopharyngeal and squamous cell carcinomas, six comparative in-silico studies consistently showed a lower dose to the parotid glands for proton therapy as opposed to IMRT (Table 2). The decrease in mean dose to the parotid glands between IMRT and proton therapy ranged from $2 \mathrm{GyE}$ to $10 \mathrm{GyE}$. Based on normal tissue complication probability (NTCP) models, three studies ${ }^{123,127,128}$ predicted probability of complications of the parotid glands (defined as a decrease of the salivary flow to $25 \%$ of the pre-treatment salivary flow). The absolute decrease (percentage points) of the complication probability of the parotid glands 
Table 1

Results of meta the analyses.

\begin{tabular}{|c|c|c|c|c|c|}
\hline Treatment & Outcome $(95 \% \mathrm{CI})$ & Comparison & Difference $(95 \% \mathrm{CI})$ & $I^{2}$ & $P$-value ${ }^{a}$ \\
\hline \multicolumn{6}{|c|}{ Nasopharyngeal carcinoma } \\
\hline & $3 Y$ LC & & & & \\
\hline IMRT & 0.947 (0.923 to 0.970$)$ & & & & \\
\hline \multirow[t]{2}{*}{ Protons ${ }^{\mathrm{b}}$} & $0.920(0.743$ to 1.000$)$ & Protons - IMRT & $-0.027(-0.232$ to 0.178$)$ & $19.0 \%$ & 0.780 \\
\hline & $\begin{array}{l}3 \mathrm{Y} \text { OS } \\
\quad 0.897(0.862 \text { to } 0.933)\end{array}$ & & & & \\
\hline Protons ${ }^{\mathrm{b}}$ & $0.740(0.471$ to 1.000$)$ & Protons - IMRT & $-0.157(-0.473$ to 0.158$)$ & $67.5 \%$ & 0.298 \\
\hline $\begin{array}{l}\text { IMRT } \\
\text { Protons }^{\mathrm{b}}\end{array}$ & $\begin{array}{c}\text { 3Y LC corrected for the ye } \\
0.946(0.927 \text { to } 0.966) \\
0.898(0.695 \text { to } 1.000)\end{array}$ & $\begin{array}{l}\text { ation } \\
\text { Protons - IMRT }\end{array}$ & $-0.048(-0.252$ to 0.156$)$ & $0.0 \%$ & 0.609 \\
\hline \multicolumn{6}{|c|}{ Oropharyngeal carcinoma } \\
\hline & $2 Y \mathrm{LC}$ & & & & \\
\hline IMRT & 0.947 (0.898 to 0.995$)$ & & & & \\
\hline Protons $^{\mathrm{b}}$ & 0.960 (0.878 to 1.000$)$ & Protons - IMRT & $0.013(-0.105$ to 0.132$)$ & $0.0 \%$ & 0.782 \\
\hline $\begin{array}{l}\text { IMRT } \\
\text { Protons }^{\mathrm{b}}\end{array}$ & $\begin{array}{l}\text { 2Y DFS } \\
\qquad \begin{array}{l}0.865(0.812 \text { to } 0.918) \\
0.810(0.662 \text { to } 0.958)\end{array}\end{array}$ & Protons - IMRT & $-0.055(-0.159$ to 0.269$)$ & $49.9 \%$ & 0.570 \\
\hline \multicolumn{6}{|c|}{ Paranasal and sinonasal carcinoma } \\
\hline IMRT & 0.662 (0.516 to 0.809$)$ & Carbon-ions - IMRT & $-0.172(-0.600$ to 0.256$)$ & & 0.327 \\
\hline Protons & $0.878(0.755$ to 1.000$)$ & Protons - IMRT & $0.216(0.025$ to 0.407$)$ & & $0.035^{\mathrm{c}}$ \\
\hline Carbon-ions $^{\mathrm{b}}$ & $0.490(0.210$ to 0.770$)$ & Protons - carbon-ions & $0.388(-0.033$ to 0.809$)$ & $0.0 \%$ & 0.063 \\
\hline $\begin{array}{l}\text { IMRT } \\
\text { Protons }\end{array}$ & $\begin{array}{l}5 Y \text { DFS } \\
0.535 \text { ( } 0.162 \text { to } 0.907) \\
0.609(0.326 \text { to } 0.891)\end{array}$ & Protons - IMRT & $0.074(-0.393$ to 0.542$)$ & $78.2 \%$ & 0.682 \\
\hline $\begin{array}{l}\text { IMRT } \\
\text { Protons }\end{array}$ & $\begin{array}{l}5 Y \text { OS } \\
\qquad 0.516(0.154 \text { to } 0.878) \\
0.705(0.414 \text { to } 0.995)\end{array}$ & Protons - IMRT & $0.188(-0.276$ to 0.653$)$ & $73.2 \%$ & 0.323 \\
\hline \multicolumn{6}{|c|}{ Mucosal malignant melanoma } \\
\hline $\begin{array}{l}\text { Photons } \\
\text { Carbon-ions }\end{array}$ & $\begin{array}{l}0.252(0.212 \text { to } 0.291) \\
0.437(0.316 \text { to } 0.558)\end{array}$ & Carbon-ions - photons & $0.185(0.058$ to 0.313$)$ & $51.7 \%$ & $0.007^{c}$ \\
\hline \multicolumn{6}{|c|}{ Adenoid cystic carcinoma } \\
\hline & $5 Y \mathrm{LC}$ & & & & \\
\hline Photons & 0.753 (0.635 to 0.870$)$ & Carbon-ions - photons & $0.061(-0.249$ to 0.371$)$ & & 0.675 \\
\hline Protons $^{\mathrm{b}}$ & $0.930(0.797$ to 1.000$)$ & Protons - photons & $0.177(-0.252$ to 0.607$)$ & & 0.386 \\
\hline \multirow[t]{2}{*}{ Carbon-ions } & $0.691(0.405$ to 0.978$)$ & Protons - carbon-ions & $0.239(-0.264$ to 0.741$)$ & $93.7 \%$ & 0.322 \\
\hline & $5 Y$ OS & & & & \\
\hline Photons & 0.731 (0.674 to 0.789 ) & Carbon-ions - photons & $-0.027(-0.203$ to 0.149$)$ & & 0.752 \\
\hline Protons ${ }^{\mathrm{b}}$ & $0.770(0.639$ to 0.901$)$ & Protons - photons & $0.039(-0.233$ to 0.310$)$ & & 0.769 \\
\hline \multirow[t]{2}{*}{ Carbon-ions } & $0.704(0.538$ to 0.871$)$ & Protons - carbon-ions & $0.066(-0.248$ to 0.379$)$ & $77.8 \%$ & 0.666 \\
\hline & $5 Y$ OS corrected for the pe & operated patient & & & \\
\hline Photons & 0.728 (0.672 to 0.784$)$ & & & & \\
\hline Protons & $0.893(0.611$ to 1.000$)$ & Protons - photons & $0.165(-0.124$ to 0.455$)$ & $73.6 \%$ & 0.245 \\
\hline
\end{tabular}

a $P$-value for the difference between the treatments.

b Consisted of only one study and the study estimated instead of the pooled estimate is therefore reported.

c Statistically significant difference.

for proton therapy compared with IMRT ranged from $6 \%$ to $28 \%$ (Table 2).

None of the included in-silico studies reported dose to the pharyngeal constrictors.

The reduced dose to organs at risk for carbon-ion and proton therapy was accomplished with a similar conformity index, dose homogeneity and coverage of the target volume for particle therapy. Hence, the decreased dose to the organs at risk will not result in a reduced tumor control probability.

\section{Discussion}

To the best of our knowledge, this review and meta-analysis was the first that reviewed all evidence (clinical and in-silico studies) and pooled the effectiveness of photon, carbon-ion and proton radiotherapy in HNC. Based on currently available evidence, we found that carbon-ion radiotherapy resulted in a statistically significantly increased 5-year OS compared to conventional photon therapy for mucosal malignant melanomas. Melanomas are considered as relatively radio-resistant tumors. ${ }^{129,130}$ Therefore, our results might indicate that carbon-ion therapy is advantageous in the treatment of relatively radio-resistant tumors in the head and neck region, which profit from the increased relative biological effectiveness (RBE). Because of lacking data, no comparisons were performed considering toxicity in mucosal malignant melanomas. Toxicity data for adenoid cystic toxicity was based on different classification systems (RTOG and CTC), which complicated the comparison. However, the incidence of toxicity for carbon-ion therapy in adenoid cystic carcinomas seemed lower than reported in conventional photon studies.

Outcomes for proton therapy were generally comparable with the best available photon therapy in nasopharyngeal, oropharyngeal and adenoid cystic carcinomas. For paranasal and sinonasal cancer, DFS and OS were comparable for photon and proton ther- 
Table 2

Dose to organs at risk and complication probability reported in comparative in-silico studies.

\begin{tabular}{|c|c|c|c|c|c|c|c|c|c|c|c|c|c|c|c|}
\hline \multirow[t]{3}{*}{ Outcome } & \multirow[t]{3}{*}{ First author } & \multirow[t]{3}{*}{$N$} & \multirow{3}{*}{$\begin{array}{l}\text { Tumor } \\
\text { histology/site }\end{array}$} & \multirow[t]{3}{*}{ OAR site } & \multicolumn{5}{|c|}{ Mean dose in Gray equivalent ${ }^{\mathrm{a}}$} & \multicolumn{6}{|c|}{ Complication probability $^{\mathrm{a}}$} \\
\hline & & & & & \multicolumn{2}{|l|}{ Photons } & \multirow{2}{*}{$\begin{array}{l}\text { Protons } \\
\text { Scanned }\end{array}$} & \multirow{2}{*}{$\begin{array}{l}\text { Carbon- } \\
\text { ions }\end{array}$} & \multirow[t]{2}{*}{ Sig. ${ }^{b}$} & \multicolumn{2}{|l|}{ Photons } & \multirow{2}{*}{$\begin{array}{l}\text { Protons } \\
\text { Scanned }\end{array}$} & \multirow{2}{*}{$\begin{array}{l}\text { Carbon- } \\
\text { ions }\end{array}$} & \multirow[t]{2}{*}{ Sig. ${ }^{b}$} & \multirow[t]{2}{*}{ NTCP model ${ }^{\mathrm{C}}$} \\
\hline & & & & & 3D-CRT & IMRT & & & & 3D-CRT & IMRT & & & & \\
\hline \multirow[t]{11}{*}{$\begin{array}{l}\text { Parotid } \\
\text { gland }\end{array}$} & $\begin{array}{l}\text { Taheri- } \\
\text { Kadkhoda et al. }{ }^{126}\end{array}$ & 8 & Nasopharynx & & - & 40 & 36 & - & Yes & - & - & - & - & - & - \\
\hline & \multirow{4}{*}{$\begin{array}{l}\text { Widesott } \\
\text { et al. }{ }^{128}\end{array}$} & \multirow[t]{4}{*}{6} & \multirow[t]{4}{*}{ Nasopharynx } & \multirow[t]{2}{*}{$\mathrm{CL}$} & \multirow[t]{2}{*}{-} & \multirow[t]{2}{*}{29} & \multirow[t]{2}{*}{23} & \multirow[t]{2}{*}{ - } & \multirow[t]{2}{*}{ Yes } & - & $22 \%$ & $5 \%$ & - & Yes & Eisbruch et al. ${ }^{136}$ \\
\hline & & & & & & & & & & - & $20 \%$ & $14 \%$ & - & Yes & Roesink et al. ${ }^{137}$ \\
\hline & & & & \multirow[t]{2}{*}{ IL } & \multirow[t]{2}{*}{ - } & \multirow[t]{2}{*}{31} & \multirow[t]{2}{*}{25} & \multirow[t]{2}{*}{-} & \multirow[t]{2}{*}{ Yes } & - & $42 \%$ & $14 \%$ & - & Yes & Eisbruch et al. ${ }^{136}$ \\
\hline & & & & & & & & & & - & $25 \%$ & $18 \%$ & - & Yes & Roesink et al. ${ }^{137}$ \\
\hline & $\begin{array}{l}\text { Van de Water } \\
\text { et al. }{ }^{127}\end{array}$ & 10 & Oropharynx & & - & 28 & 18 & - & Yes & - & $41 \%$ & $21 \%$ & - & Yes & $\begin{array}{l}\text { Semenenko and } \\
\mathrm{Li}^{138}\end{array}$ \\
\hline & & 5 & Hypopharynx & Left & 48 & 42 & 33 & - & $\mathrm{nr}$ & $94 \%$ & $65 \%$ & $40 \%$ & - & $\mathrm{nr}$ & Schilstra and \\
\hline & et al. ${ }^{123}$ & & & Right & 47 & 35 & 33 & - & $\mathrm{nr}$ & $93 \%$ & $51 \%$ & $43 \%$ & - & $\mathrm{nr}$ & Meertens ${ }^{139}$ \\
\hline & Cozzi et al. ${ }^{122}$ & 5 & Squamous cell & Left & 49 & 46 & 40 & - & $\mathrm{nr}$ & - & - & - & - & - & - \\
\hline & & & carcinomas & Right & 48 & 44 & 36 & - & $\mathrm{nr}$ & - & - & - & - & - & - \\
\hline & $\begin{array}{l}\text { Steneker } \\
\text { et al. }{ }^{125}\end{array}$ & 5 & $\begin{array}{l}\text { Squamous cell } \\
\text { carcinomas }\end{array}$ & & - & $\approx 55 \%^{\mathrm{d}}$ & $\approx 35 \%^{\mathrm{d}}$ & - & $\mathrm{nr}$ & - & - & - & - & - & - \\
\hline Optic & Mock et al. ${ }^{124}$ & 5 & Paranasal sinus & $\mathrm{CL}$ & $66 \%^{\mathrm{d}}$ & $62 \%^{\mathrm{d}}$ & $51 \%$ d,e & - & $\mathrm{nr}$ & - & - & - & - & - & - \\
\hline nerve & & & & IL & $95 \%^{\mathrm{d}}$ & $91 \%^{\mathrm{d}}$ & $90 \%$ d,e & - & $\mathrm{nr}$ & - & - & - & - & - & - \\
\hline & Amirul Islam & 7 & Paranasal sinus & $\mathrm{CL}$ & 42 & 44 & - & 24 & Yes & - & - & - & - & - & - \\
\hline & et al. ${ }^{121}$ & & & IL & 58 & 58 & - & 54 & No & - & - & - & - & - & - \\
\hline
\end{tabular}

Abbreviations: $\mathrm{CL}=$ contralateral, $\mathrm{IL}=$ ipsilateral, $\mathrm{OAR}=$ organ at risk, Sig = statistically significance, $\mathrm{NTCP}=$ normal tissue complication probability, and $\mathrm{nr}=$ not reported.

a The optimal outcome per study is printed in bold.

b Statistically significance of the comparison IMRT versus proton/carbon-ion therapy ( $P$-value $\leqslant 0.05$ is considered statistically significant).

c Endpoints for the complication probability of the parotid gland: decrease of the salivary flow to $25 \%$ of pre-treatment flow at 13 weeks (Schilstra and Meertens ${ }^{139}$ ), 6 months (Semenenko and $\mathrm{Li}^{138}$ ) or 1 year (Eisbruch et al. ${ }^{136}$ and Roesink et al. ${ }^{137}$ ) after radiotherapy.

d Dose to organ at risk presented as\% of the prescribed dose.

e Protons scattered.

apy. Nevertheless, LC was statistically significantly increased for proton therapy. Besides a higher total treatment dose, this increase may also be influenced by the proportion of patients that received surgery (Appendix 4). ${ }^{72}$ For the remainder, the similar outcomes can be explained since the radiobiological differences between protons and photons are small and the total treatment doses among studies were generally comparable. Considering treatment toxicity in oropharyngeal cancer and nasopharyngeal cancer, no appropriate data concerning xerostomia or dysphagia were available to perform comparisons based on clinical data. Although based on different classification systems, in paranasal and sinonasal cancer the incidence of grade 3 visual toxicity seemed lower for proton therapy as compared to photon therapy.

In paranasal carcinomas, one comparative in-silico studies showed a reduced dose to the optic nerves for carbon-ion therapy compared to photon therapy. ${ }^{121}$ Nonetheless, it is not yet clear how this decrease in dose translates into clinical outcomes. For proton therapy compared to photon therapy, we found a decreased dose to the optical nerves ${ }^{124}$ and to the parotid glands. ${ }^{122-128}$ Based on NTCP models, this latter dose reduction resulted in a lower complication probability for the parotid glands. ${ }^{123,127,128}$ However, the reported complication probabilities varied largely among the in-silico studies, which is partly due to differences in the applied NTCP models. The decreased dose to the organs at risk was accomplished without compromising on the conformity index, dose homogeneity and coverage of the target volume. ${ }^{122-128}$ This indicates that the main advantage of proton therapy in HNC may currently be the ability to spare organs at risk without decreasing tumor control rates. However, clinical evidence to support this is not yet available.

To explore potential confounding factors and subsequently correct for heterogeneity between studies we included covariates in our analyses. In two analyses, statistically significantly influencing covariates were observed. Firstly, the year of publication was statistically significant in the analyses concerning 3-year LC in naso- pharyngeal carcinomas, which might reflect changes over time such as the inclusion of more patients with nodal extension in more recent studies (Appendix 4). However, this covariate did not substantially affect the estimated 3-year LC. Secondly, in the analyses considering adenoid cystic carcinomas, the proportion of operated patients had a statistically significant influence on 5-year OS. The estimate for conventional photon therapy remained unchanged whereas the 5-year OS for proton therapy increased substantially (Fig. 1 and Table 1). The remaining analyses did not reveal other covariates which statistically significantly influenced the outcomes.

Radiotherapy was often combined with chemotherapy and/or surgery in the included studies. Since our analyses were restricted to group-level data and study outcomes were not stratified for chemotherapy and surgery, we were not able to clarify the individual impact of chemotherapy or the positioning of surgery. It would be an interesting topic for future research to examine whether and when proton or carbon-ion radiotherapy could best be combined with chemotherapy and/or surgery.

Further, the potential gain of particle therapy in terms of tumor control may rely on higher doses to the tumor while remaining an equal dose to the organs at risk. Correcting for differences in treatment dose would therefore remove the potential gain of particle therapy. For that reason, our analyses were not corrected for differences in radiotherapy dosage schemes.

The present study has some limitations. Most importantly, the evidence on the effectiveness of particle therapy consists of a limited number of (mainly small) observational studies. Also, influencing variables were not always reported adequately. As a consequence correcting for confounding variables was only possible to a limited extent. These data issues may bias the comparisons as a result of differences in setting or treatment properties. This is considered a main drawback of meta-analysis of observational studies. ${ }^{33,131}$ However, in the absence of randomized trials, meta-analysis of observational studies is one of the 
few methods to synthesize effectiveness and present uncertainty ${ }^{33}$ and follows the recommendation that all relevant studies should be taken into account. ${ }^{132}$ Another data concern was the scarcely reported toxicity data among studies, and as a result it was not possible to adequately compare late treatment toxicity based on clinical data.

\section{Implications for practice}

It has been subject of debate whether the high initial and treatment costs of particle therapy are justified given the currently available evidence surrounding its effectiveness. ${ }^{21}$ Based on the available evidence, particle therapy seems as least as effective as photon therapy in tumor control, and may have advantages in sparing organs at risk. However, with regard to the paucity of available proton and carbon-ion studies and the potential bias of comparisons between (small) observational studies, the superiority of particle therapy in terms of tumor control and survival as well as the question whether the benefits outweighs the costs remains uncertain.

\section{Implications for research}

Particles are used in the treatment of cancer since $1954 .{ }^{133}$ However, the number of published studies which administer particle therapy in HNC is limited and much of the currently available data have been gathered in less than optimal physic-based settings. Therefore, it is difficult to establish the potential effectiveness of particle therapy in more optimal clinical settings. Studies evaluating the effectiveness of particle therapy in HNC stratified by location and/or histology are therefore needed.

Curative radiation therapy for HNC is often accompanied with a trade-off between radiation toxicity and survival. The length of survival alone is therefore insufficient to determine the success of a treatment, and the quality of survival needs to be considered simultaneously. ${ }^{134}$ However, complete (late) treatment toxicity data is infrequently and inconsistently reported. Hence, there is a need for studies to systematically examine both minor and severe radiation toxicity per type and grade. This is especially important if decreasing treatment toxicity is regarded as the potential benefit of particle therapy in HNC.

As recommended previously, ${ }^{15}$ to facilitate comparisons on both survival and treatment toxicity between particle therapy and photon radiation; the construction of an international particle therapy register, which contains anonymous data from patients who have been treated with particle therapy, would be a straightforward and effective solution. Such registries become particularly evident if randomized trials comparing photon therapy and particle therapy are not to be expected. ${ }^{135}$

For now, in the absence of comprehensive toxicity data, comparative in-silico studies combined with dose-response models offer a complementary way of estimating the potential added value of particle therapy in HNC in relation to its costs. ${ }^{20,22}$

\section{Conclusions}

Currently available clinical evidence for HNC indicates that survival for carbon-ion radiotherapy in mucosal malignant melanomas is statistically significantly increased as opposed to photon radiation. This suggests that carbon-ion radiotherapy, with its increased biological efficacy, might be advantageous in the treatment of relatively radio-resistant tumors. Besides local control in paranasal and sinonasal cancer, survival and tumor control outcomes for proton therapy were to a large extent similar to the best available photon radiation. Based on limited data, this review indi- cates that a clinically relevant benefit of proton therapy probably lies in reducing treatment toxicity in HNC. This finding is in accordance with available comparative in-silico studies.

Since the overall quantity and quality of data regarding carbonion and proton therapy is poor and considering the risk of bias in comparisons between (small) observational studies, the reported results do not allow for definite conclusions. Therefore, we recommend the construction of an international particle therapy register to facilitate definitive comparisons on both survival and treatment toxicity between particle and photon radiotherapy.

\section{Conflict of interest statement}

No actual or potential conflicts of interest exist.

\section{Funding source}

None.

\section{Acknowledgement}

Jun-etsu Mizoe, Luca Cozzi and Antonella Fogliata are gratefully acknowledged for providing additional data.

\section{Appendix 1. Detailed overview of the search queries}

Search query 1: particle therapy studies.

\section{Patient}

\#1 "Salivary gland” OR "oropharyngeal" OR "oropharynx" OR "nasopharynx" OR "nasopharyngeal" OR "paranasal sinus" OR "paranasal” OR "hypopharynx" OR "pharynx" OR "oral cavity"

\#2 (Neoplasm) OR “cancer" OR "tumor" OR "tumour” OR (malignan) OR (oncol) OR (carcinoma) OR (head and neck neoplasms [mesh])

\#3 \#1 AND \#2

\#4 (Carcinoma, adenoid cystic/radiotherapy [mesh]) OR (neoplasms, squamous cell [mesh]) OR (melanoma [mesh]) OR "adenoid cystic" OR "squamous cell" OR "melanoma” OR “cancer” OR (neoplasm) OR "tumor” OR "tumour" OR (malignan) OR (oncol)

\#5 (("Cancer" OR (neoplasm) OR "tumor" OR "tumour" OR (malignan) OR (oncol) OR (carcinoma)) AND head neck) OR (head and neck neoplasms [mesh])

\#6 \#4 AND \#5

\#7 ((Head and neck neoplasms [mesh]) OR (salivary gland neoplasms [mesh]) OR (oropharyngeal neoplasms [mesh]) OR (nasopharyngeal neoplasms [mesh]) OR (pharyngeal neoplasms [mesh]) OR (paranasal sinus neoplasms [mesh]))

\#8 \#3 OR \#6 OR \#7

Intervention and comparison

\#9 (proton therap) OR "proton"

\#10 "particle" OR (heavy ion) OR (light ion) OR "hadron" OR "carbon"

\#11 “beam irradiation” OR “radiation" OR “irradiation” OR "beam radiation" OR (radiotherap) OR (beam therap)

\#12 \#11 OR (ion therap)

\#13 \#9 AND \#11

\#14 \#10 AND \#12

\#15 (Protons/therapeutic use [mesh]) OR (carbon radioisotopes/therapeutic use [mesh])

\#16 \#13 OR \#14 OR \#15 


\section{Outcome}

\#17 "Mortality" OR (adverse effect) OR (adverse event) OR (side effect) OR (toxicit) OR (xerostomi) OR "disease free survival" OR "overall survival” OR "local control" OR "tumour control" OR "tumour control"

\#18 (Mortality [mesh]) OR (head and neck neoplasms/ mortality [mesh]) OR (treatment outcome [mesh]) OR ("outcome assessment (health care)" [mesh]) OR (adverse effects [subheading]) OR (radiotherapy/ adverse effects [mesh]) OR (sickness impact profile [mesh]) OR (survival rate [mesh]) OR ("xerostomia" [mesh]) OR (disease free survival [mesh])

\#19 \#17 OR \#18

PICO = \#8 AND \#16 AND \#19

Search query 2: intensity modulated radiotherapy studies.

\section{Patient}

\#1 "Salivary gland” OR "oropharyngeal” OR "oropharynx" OR "nasopharynx" OR "nasopharyngeal” OR "paranasal sinus" OR "paranasal” OR "hypopharynx" OR "pharynx" OR "oral cavity"

\#2 (Neoplasm*) OR “cancer" OR "tumor" OR "tumour" OR (malignan*) OR (oncol*) OR (carcinoma*) OR (head and neck neoplasms [mesh])

\#3 \#1 AND \#2

\#4 (Carcinoma, adenoid cystic/*radiotherapy [mesh]) OR (neoplasms, squamous cell [mesh]) OR (melanoma [mesh]) OR "adenoid cystic" or "squamous cell" OR "melanoma” OR "cancer" OR (neoplasm*) OR "tumor" OR "tumour" OR (malignan*) OR (oncol*)

\#5 ((“Cancer" OR (neoplasm*) OR "tumor" OR "tumour" OR (malignan*) OR (oncol*) OR (carcinoma*)) AND head neck) OR (head and neck neoplasms [mesh])

\#6 \#4 AND \#5

\#7 ((head and neck neoplasms [mesh]) OR (salivary gland neoplasms [mesh]) OR (oropharyngeal neoplasms [mesh]) OR (nasopharyngeal neoplasms [mesh]) OR (pharyngeal neoplasms[mesh]) OR (paranasal sinus neoplasms [mesh]))

\#8 \#3 OR \#6 OR \#7

Intervention and comparison

\#9 ((Intensity modulated) AND ((radiotherap*) OR (radiotherapy [subheading]) OR (radiotherapy [mesh]))) OR "IMRT" OR (radiotherapy, intensity modulated [mesh])

\section{Outcome}

\#10 "Mortality" OR (adverse effect*) OR (adverse event*) OR (side effect*) OR (toxicit*) OR (xerostomi*) OR "disease free survival" OR "overall survival" OR "local control” OR "tumor control" OR "tumour control"

\#11 (Mortality [mesh]) OR (head and neck neoplasms/ *mortality [mesh]) OR (treatment outcome [mesh]) OR ("outcome assessment (health care)"[mesh]) OR (adverse effects [subheading]) OR (radiotherapy/ adverse effects [mesh]) OR (sickness impact profile [mesh]) OR (survival rate [mesh]) OR ("xerostomia"[mesh]) OR (disease free survival [mesh]) \#12 \#10 OR \#11

$\mathrm{PICO}=\# 8$ AND \#9 AND \#12

*For mucosal malignant melanoma and adenoid cystic carcinomas, no studies using intensity modulated radiotherapy were available.
Search query 3: conventional radiotherapy studies for mucosal malignant melanoma and adenoid cystic carcinomas*.

Patient

\#1 "Salivary gland” OR “oropharyngeal” OR "oropharynx" OR "nasopharynx" OR "nasopharyngeal” OR "paranasal Sinus" OR "paranasal" OR "hypopharynx" OR "pharynx" OR "oral cavity"

\#2 (Neoplasm*) OR “cancer" OR "tumor" OR “tumour" OR (malignan*) OR (oncol*) OR (carcinoma*) OR (head and neck neoplasms [mesh])

\#3 \#1 AND \#2

\#4 (Melanoma [mesh]) OR “melanoma” OR (carcinoma, adenoid cystic/*radiotherapy [mesh]) OR "adenoid cystic"

\#5 (("Cancer" OR (neoplasm*) OR "tumor" OR "tumour" OR (malignan*) OR (oncol*) OR (carcinoma*)) AND head neck) OR (head and neck neoplasms [mesh])

\#6 \#4 AND \#5

\#7 ((Head and neck neoplasms [mesh]) OR (salivary gland neoplasms [mesh]) OR (oropharyngeal neoplasms [mesh]) OR (nasopharyngeal neoplasms [mesh]) OR (pharyngeal neoplasms [mesh]) OR (paranasal sinus neoplasms [mesh]))

\#8 (\#3 OR \#7) AND (\#6)

Intervention and comparison

\#9 (Radiotherap*) OR (radiotherapy [subheading]) OR (radiotherapy [mesh])

\section{Outcome}

\#10 "Mortality" OR (adverse effect*) OR (adverse event*) OR (side effect*) OR (toxicit*) OR (xerostomi*) OR "disease free survival" OR "overall survival" OR "local control" OR "tumor control" OR "tumour control"

\#11 (Mortality [mesh]) OR (head and neck neoplasms/ *mortality [mesh]) OR (treatment outcome [mesh]) OR ("outcome assessment (health care)"[Mesh]) OR (adverse effects [subheading]) OR (radiotherapy/ adverse effects [mesh]) OR (sickness impact profile [mesh]) OR (survival rate [mesh]) OR ("xerostomia"[mesh]) OR (disease free survival [mesh])

\#12 \#10 OR \#11

$\mathrm{PICO}=\# 8$ AND \#9 AND \#12

*For mucosal malignant melanoma and adenoid cystic carcinomas, no studies using intensity modulated radiotherapy were available.

Search query 4: comparative in-silico studies.

Patient

\#1 "Salivary gland" OR “oropharyngeal" OR "oropharynx" OR "nasopharynx" OR "nasopharyngeal” OR "paranasal Sinus" OR "paranasal" OR "hypopharynx" OR "pharynx" OR "oral cavity"

\#2 (Neoplasm) OR “cancer" OR "tumor" OR "tumour” OR (malignan) OR (oncol) OR (carcinoma) OR (head and neck neoplasms [mesh])

\#3 \#1 AND \#2

\#4 (Carcinoma, adenoid cystic/radiotherapy [mesh]) OR (neoplasms, squamous cell [mesh]) OR (melanoma [mesh]) OR "adenoid cystic" OR "squamous cell" OR "melanoma” OR “cancer" OR (neoplasm) OR "tumor” OR "tumor" OR (malignan) OR (oncol)

\#5 ((“Cancer" OR (neoplasm) OR "tumor" OR "tumor" OR (malignan) OR (oncol) OR (carcinoma)) AND head neck) OR (head and neck neoplasms [mesh])

(continued on next page) 


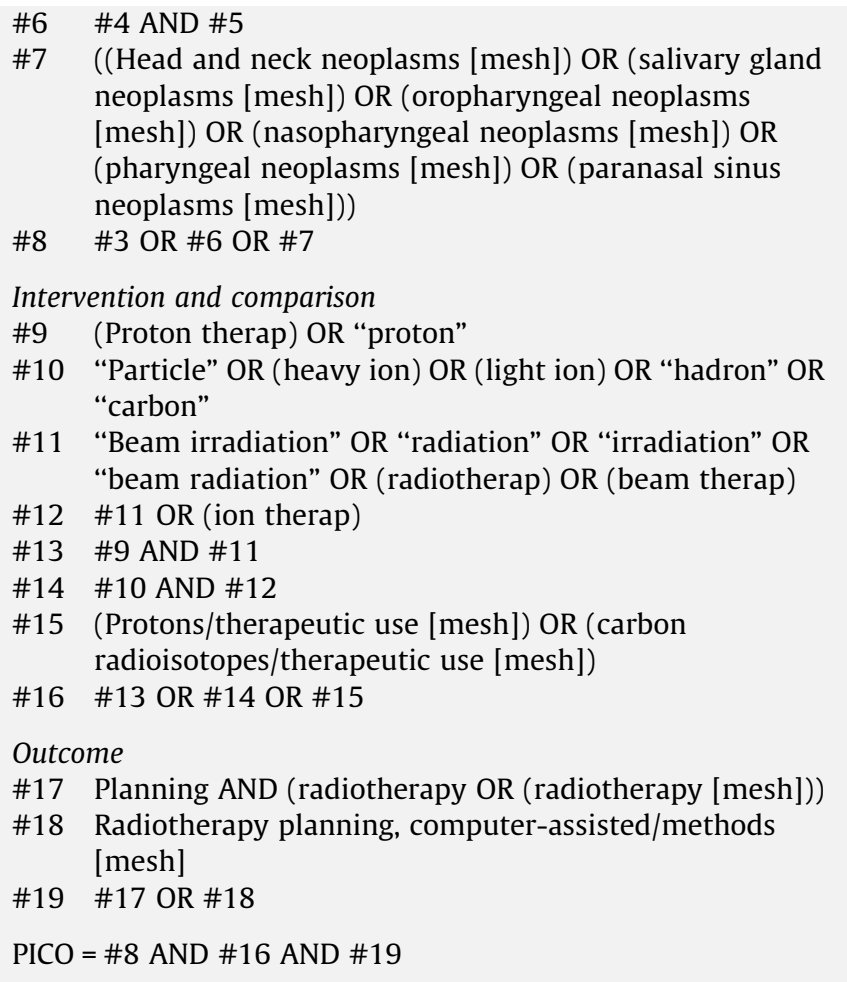

\section{Appendix 2. Flow chart of the inclusion and exclusion process for the search strategies}

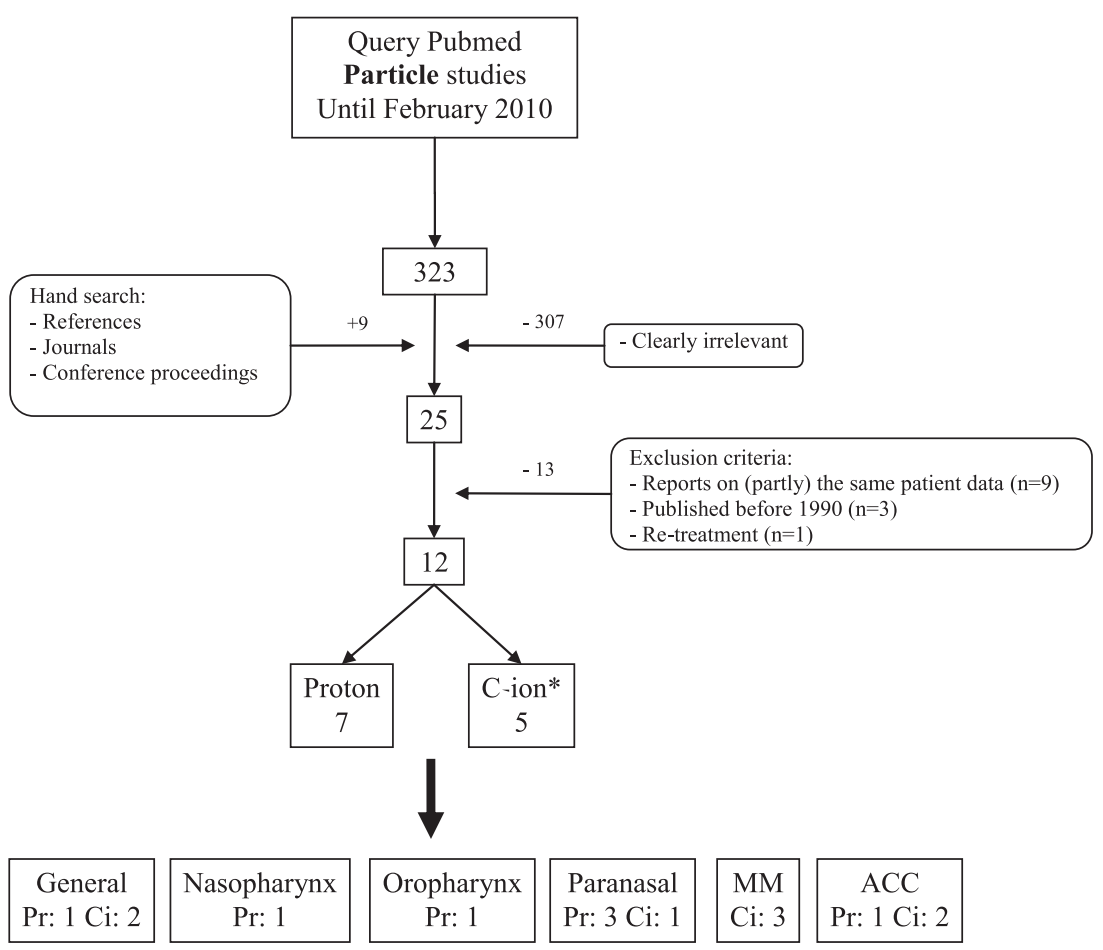

* Data/sub-analysis extracted from two carbon-ion studies were used in multiple subgroups

Abbreviations: $\operatorname{Pr}=$ Proton therapy, $\mathrm{Ci} / \mathrm{C}$-ions $=$ carbon-ion therapy, $\mathrm{MM}=$ mucosal malignant melanomas, $\mathrm{ACC}=$ adenoid cystic carcinomas 


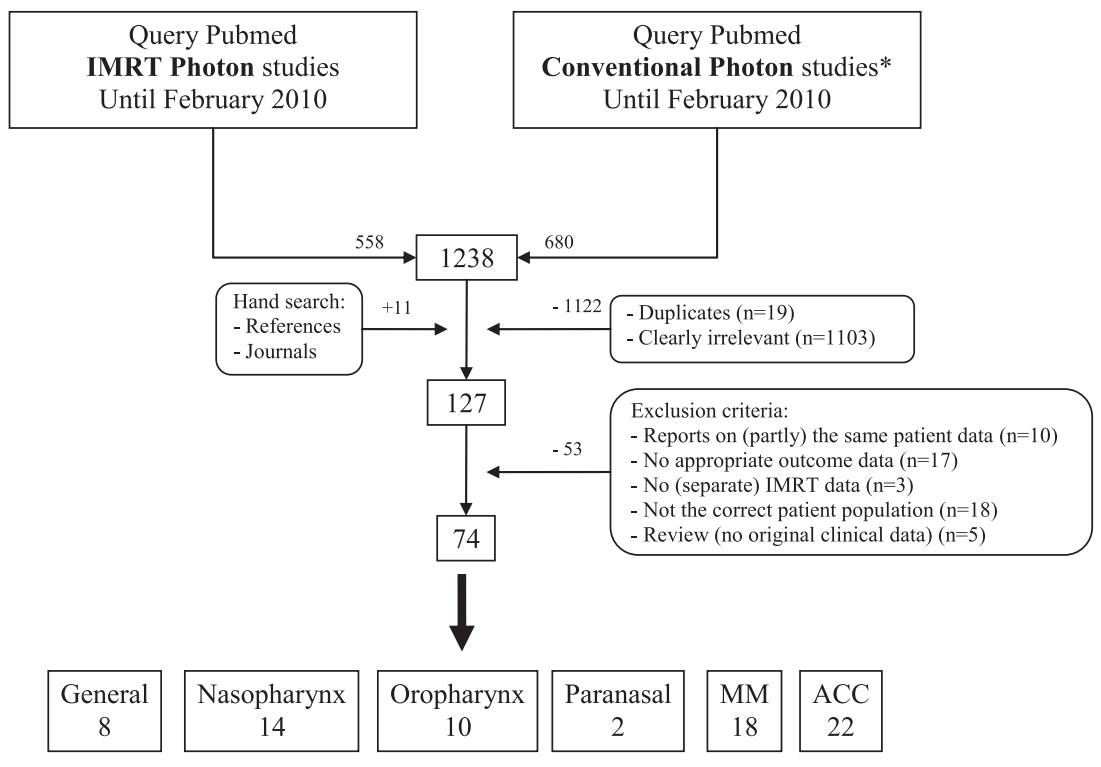

* Search query specified for mucosal malignant melanomas and adenoid cystic carcinomas (for these subgroups no IMRT studies were available).

Abbreviations: $\mathrm{IMRT}=$ intensity modulated radiotherapy, $\mathrm{MM}=$ mucosal malignant melanomas, $\mathrm{ACC}=$ adenoid cystic carcinomas

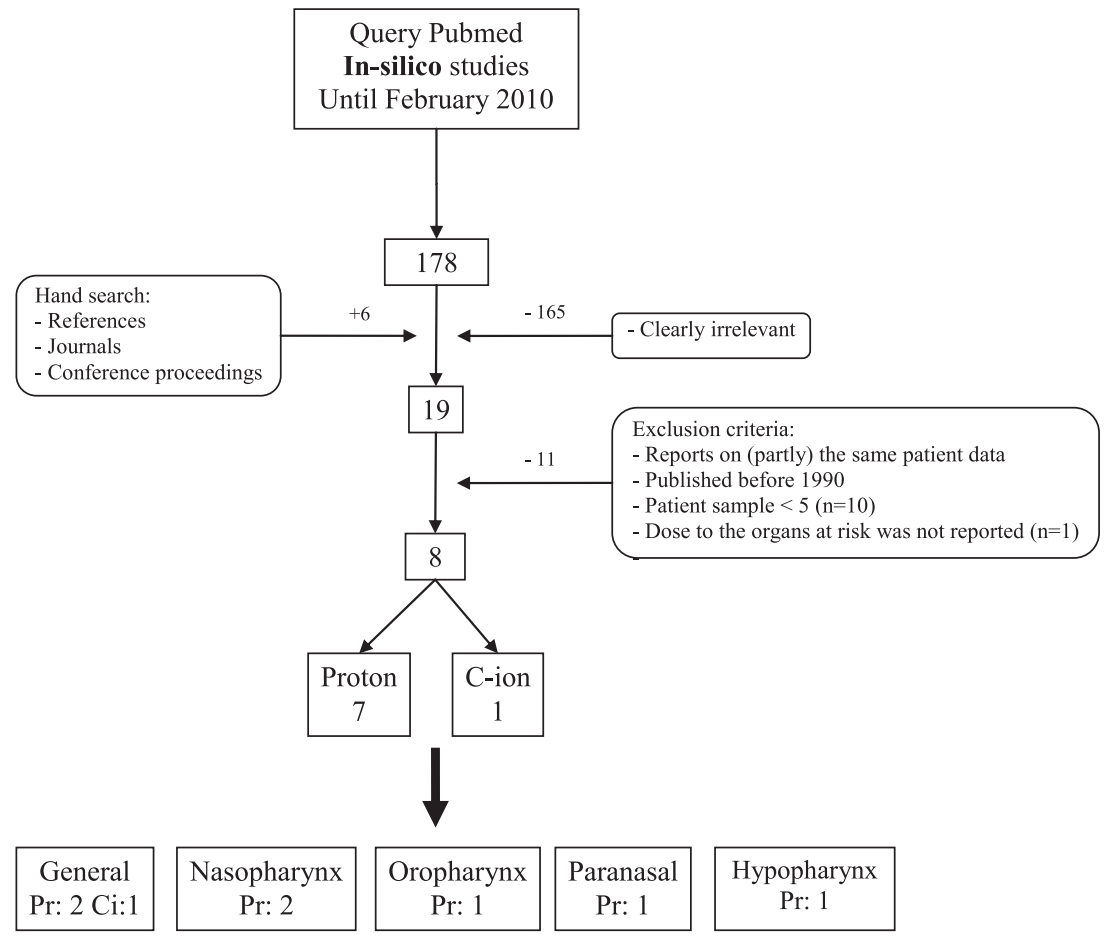

Abbreviations: $\mathrm{Pr}=$ Proton therapy, $\mathrm{Ci} / \mathrm{C}$-ion $=$ carbon-ion therapy, $\mathrm{ACC}=$ adenoid cystic carcinomas 
Appendix 3. Included and excluded particle studies and in-silico

Included clinical studies.

\begin{tabular}{|c|c|c|}
\hline $\begin{array}{l}\text { First } \\
\text { author }\end{array}$ & Year & Comparison(s) (outcomes) \\
\hline Resto & 2009 & $\begin{array}{l}\text { Paranasal and sinonasal carcinoma (LC, } \\
\text { DFS and OS) }\end{array}$ \\
\hline Nishimura & 2009 & $\begin{array}{l}\text { Paranasal and sinonasal carcinoma (LC, } \\
\text { DFS, OS, and toxicity) }\end{array}$ \\
\hline Mizoe & 2009 & Mucosal malignant melanoma (OS) \\
\hline Mizoe & 2009 & $\begin{array}{l}\text { Head and neck cancer (LC and OS), } \\
\text { mucosal malignant melanoma (OS), } \\
\text { adenoid cystic carcinoma (LC and OS) }\end{array}$ \\
\hline Munter & 2009 & $\begin{array}{l}\text { Adenoid cystic carcinoma (LC, OS and } \\
\text { toxicity) }\end{array}$ \\
\hline Yanagi & 2009 & Mucosal malignant melanoma (toxicity) \\
\hline Pommier & 2006 & Adenoid cystic carcinoma (LC and OS) \\
\hline Weber & 2006 & $\begin{array}{l}\text { Paranasal and sinonasal carcinoma } \\
\text { (toxicity) }\end{array}$ \\
\hline Slater & 2005 & Oropharyngeal carcinoma (LC and DFS) \\
\hline Chan & 2004 & Nasopharyngeal carcinoma (LC and OS) \\
\hline Mizoe & 2004 & $\begin{array}{l}\text { Head and neck cancer (LC and OS), } \\
\text { paranasal and sinonasal carcinoma (LC) }\end{array}$ \\
\hline Tokuuye & 2004 & Head and neck cancer (LC,DFS and OS) \\
\hline
\end{tabular}

Excluded clinical studies.

\begin{tabular}{|c|c|c|}
\hline First author & Year & Reason(s) for exclusion \\
\hline Truong & 2009 & $\begin{array}{l}\text { Overlap in patient sample (with Resto } \\
\text { et al., 2008) }\end{array}$ \\
\hline Takagi & 2007 & $\begin{array}{l}\text { Overlap in patient sample (with Mizoe } \\
\text { et al., 2009) }\end{array}$ \\
\hline Chan & 2004 & $\begin{array}{l}\text { Overlap in patient sample (with Resto } \\
\text { et al., 2008) }\end{array}$ \\
\hline $\begin{array}{l}\text { Schulz- } \\
\text { Ertner }\end{array}$ & 2005 & $\begin{array}{l}\text { Overlap in patient sample (with Munter } \\
\text { et al., 2009) }\end{array}$ \\
\hline $\begin{array}{l}\text { Schulz- } \\
\text { Ertner }\end{array}$ & 2004 & $\begin{array}{l}\text { Overlap in patient sample (with Munter } \\
\text { et al., 2009) }\end{array}$ \\
\hline $\begin{array}{l}\text { Schulz- } \\
\text { Ertner }\end{array}$ & 2003 & $\begin{array}{l}\text { Overlap in patient sample (with Munter } \\
\text { et al., 2009) }\end{array}$ \\
\hline Fitzek & 2002 & $\begin{array}{l}\text { Overlap in patient sample (with Resto } \\
\text { et al., 2008) }\end{array}$ \\
\hline Lin & 1999 & Re-treatment \\
\hline Thornton & 1998 & $\begin{array}{l}\text { Overlap in patient sample (with Resto } \\
\text { et al., 2008) }\end{array}$ \\
\hline Tsujii & 1992 & $\begin{array}{l}\text { Overlap in patient sample (with } \\
\text { Tokuuye et al., 2004) }\end{array}$ \\
\hline Castro & 1988 & $\begin{array}{l}\text { Published before } 1990 \text { and other } \\
\text { particles than protons and carbon-ions } \\
\text { only (including He, C, Ne and Si) }\end{array}$ \\
\hline Munzenrider & 1985 & Published before 1990 \\
\hline Castro & 1982 & Published before 1990 \\
\hline
\end{tabular}

\begin{tabular}{|c|c|c|}
\hline First author & Year & Tumor site/histology \\
\hline Amirul Islam & 2008 & $\begin{array}{l}\text { In close proximity of the optic } \\
\text { pathways }\end{array}$ \\
\hline $\begin{array}{l}\text { Taheri- } \\
\text { Kadkhoda }\end{array}$ & 2008 & Nasopharynx \\
\hline Van de Water & 2008 & Oropharynx \\
\hline Widesott & 2008 & Nasopharynx \\
\hline Steneker & 2006 & Squamous cell carcinoma \\
\hline Johansson & 2004 & Hypopharynx \\
\hline Mock & 2004 & Paranasal sinus \\
\hline Cozzi & 2001 & Squamous cell carcinoma \\
\hline
\end{tabular}

Excluded comparative in-silico studies.

\begin{tabular}{lll}
\hline First author & Year & Reason(s) for exclusion \\
Chera & 2009 & Patients sample $<5$ \\
Thorwarth & 2008 & Patients sample $<5$ \\
Muzik & 2008 & Patients sample $<5$ \\
Flynn & 2008 & Patients sample $<5$ \\
Lomax & 2003 & Patients sample $<5$ \\
Schulz- & 2003 & $\begin{array}{l}\text { Dose to the organs at risk was not } \\
\text { reported }\end{array}$ \\
$\begin{array}{ll}\text { Ertner } \\
\text { Lomax }\end{array}$ & $1999 \begin{array}{l}\text { Patients sample }<5 \text { and no comparison } \\
\text { of particle therapy and photons }\end{array}$ \\
Lomax & 1999 & $\begin{array}{l}\text { Patients sample }<5 \\
\text { Slater } \\
\text { Mirabell }\end{array}$ \\
Brown & 1992 & $\begin{array}{l}\text { Patients sample }<5 \\
\text { Patients sample }<5\end{array}$ \\
& 1989 & $\begin{array}{l}\text { Patients sample }<5 \text { and published before } \\
1990\end{array}$ \\
\hline
\end{tabular}


Appendix 4A. Characteristics of nasopharyngeal and oropharyngeal studies*

\begin{tabular}{|c|c|c|c|c|c|c|c|c|c|c|c|c|}
\hline & $N$ & Modality & $\begin{array}{l}\text { Number of } \\
\text { fractions }^{\dagger}\end{array}$ & $\begin{array}{l}\text { Total treatment } \\
\text { dose }(\mathrm{GyE})^{\dagger}\end{array}$ & $\mathrm{Age}^{\dagger}$ & $\% \mathrm{Ct}$ & $\begin{array}{l}\% \text { Operated } \\
\text { patients }\end{array}$ & $\begin{array}{l}\% \mathrm{~T} 3 / \\
\mathrm{T} 4\end{array}$ & $\% \mathrm{~T} 4$ & $\% \mathrm{~N}+$ & $\begin{array}{l}\% \\
\text { N3 }\end{array}$ & $\begin{array}{l}\% \\
\text { Stage } \\
\text { IV }\end{array}$ \\
\hline \multicolumn{13}{|l|}{ Nasopharynx } \\
\hline $\begin{array}{l}\text { Chan et al. } \\
(2004)^{45}\end{array}$ & 17 & $\begin{array}{l}\text { P-rt + X- } \\
\text { rt }\end{array}$ & 46 & 73.6 & 41 & $59 \%$ & $0 \%$ & $100 \%$ & $100 \%$ & $53 \%$ & $6 \%$ & $100 \%$ \\
\hline $\begin{array}{l}\text { Zheng et al. } \\
(2010)^{59}\end{array}$ & 59 & X-rt & 33 & 70.7 & 48 & $100 \%$ & $\mathrm{nr}$ & $50 \%$ & $28 \%$ & $85 \%$ & $20 \%$ & $43 \%$ \\
\hline $\begin{array}{l}\text { Kim et al. } \\
(2009)^{49}\end{array}$ & 25 & X-rt & 30 & 67.5 & 44 & $100 \%$ & $0 \%$ & $44 \%$ & $24 \%$ & $96 \%$ & $24 \%$ & $48 \%$ \\
\hline $\begin{array}{l}\text { Lee et al. } \\
\qquad(2009)^{52}\end{array}$ & 68 & X-rt & 33 & 70.0 & 49 & $84 \%$ & $0 \%$ & $34 \%$ & $19 \%$ & $74 \%$ & $12 \%$ & $28 \%$ \\
\hline $\begin{array}{l}\text { Lin et al. } \\
\qquad(2009)^{54}\end{array}$ & 323 & X-rt & $30 / 31$ & $66.0 / 69.8$ & $\mathrm{nr}$ & $91 \%$ & $0 \%$ & $61 \%$ & $24 \%$ & $91 \%$ & $6 \%$ & $29 \%$ \\
\hline $\begin{array}{l}\text { Nishimura } \\
\text { et al. } \\
(2009)^{55}\end{array}$ & 35 & $\mathrm{X}-\mathrm{rt}$ & $28-35$ & 68.0 & 56 & $89 \%$ & $\mathrm{nr}$ & $46 \%$ & $26 \%$ & $66 \%$ & $11 \%$ & $34 \%$ \\
\hline $\begin{array}{l}\text { Tham et al. } \\
(2009)^{56}\end{array}$ & 195 & X-rt & 35 & 70.0 & 52 & $56 \%$ & $0 \%$ & $\mathrm{nr}$ & $26 \%$ & $\mathrm{nr}$ & $\mathrm{nr}$ & $30 \%$ \\
\hline $\begin{array}{l}\text { Wong et al. } \\
(2009)^{58}\end{array}$ & 175 & X-rt & 33 & 70.0 & 48 & $73 \%$ & $0 \%$ & $35 \%$ & $15 \%$ & $72 \%$ & $9 \%$ & $24 \%$ \\
\hline $\begin{array}{l}\text { Fang et al. } \\
(2008)^{47}\end{array}$ & 110 & X-rt & $36-42$ & $64.8-75.6$ & $\mathrm{nr}$ & $57 \%$ & $0 \%$ & $25 \%$ & $11 \%$ & $68 \%$ & $1 \%$ & $12 \%$ \\
\hline $\begin{array}{l}\text { Koom et al. } \\
(2008)^{50}\end{array}$ & 24 & X-rt & 27 & 64.8 & 46 & $100 \%$ & $0 \%$ & $29 \%$ & $13 \%$ & $96 \%$ & $25 \%$ & $33 \%$ \\
\hline $\begin{array}{l}\text { Wolden et al. } \\
(2006)^{57}\end{array}$ & 74 & X-rt & 30 & 70.2 & 45 & $93 \%$ & $0 \%$ & $51 \%$ & $31 \%$ & $78 \%$ & $24 \%$ & $47 \%$ \\
\hline $\begin{array}{l}\text { Chong et al. } \\
(2004)^{46}\end{array}$ & 104 & X-rt & $25-30$ & $64.0-70.0$ & 43 & $\mathrm{nr}$ & $\mathrm{nr}$ & $\mathrm{nr}$ & $\mathrm{nr}$ & $\mathrm{nr}$ & $\mathrm{nr}$ & $16 \%$ \\
\hline $\begin{array}{l}\text { Kam et al. } \\
\qquad(2004)^{48}\end{array}$ & 63 & $\mathrm{X}-\mathrm{rt}$ & 33 & 66.0 & 48 & $30 \%$ & $0 \%$ & $51 \%$ & $19 \%$ & $70 \%$ & $5 \%$ & $22 \%$ \\
\hline $\begin{array}{l}\text { Kwong et al. } \\
(2004)^{51}\end{array}$ & 33 & X-rt & 34 & $68.0-70.0$ & 43 & $0 \%$ & $0 \%$ & $3 \%$ & $0 \%$ & $18 \%$ & $0 \%$ & $0 \%$ \\
\hline $\begin{array}{l}\text { Lee et al. } \\
\qquad(2002)^{53}\end{array}$ & 67 & X-rt & $\mathrm{nr}$ & $65.0-70.0$ & 49 & $75 \%$ & $0 \%$ & $43 \%$ & $21 \%$ & $78 \%$ & $12 \%$ & $37 \%$ \\
\hline \multicolumn{13}{|l|}{ Oropharynx } \\
\hline $\begin{array}{l}\text { Slater et al. } \\
(2005)^{60}\end{array}$ & 29 & $\begin{array}{l}\text { P-rt + X- } \\
\mathrm{rt}\end{array}$ & 45 & 75.9 & $\mathrm{nr}$ & $0 \%$ & $0 \%$ & $55 \%$ & $21 \%$ & $83 \%$ & $10 \%$ & $62 \%$ \\
\hline $\begin{array}{l}\text { Daly et al. } \\
(2010)^{70}\end{array}$ & 107 & X-rt & 30 & $60.0 / 66.0$ & $\mathrm{nr}$ & $80 \%$ & $21 \%$ & $47 \%$ & $29 \%$ & $91 \%$ & $11 \%$ & $86 \%$ \\
\hline $\begin{array}{l}\text { Eisbruch et al. } \\
(2009)^{62}\end{array}$ & 67 & X-rt & 30 & 66.0 & 56 & $0 \%$ & $0 \%$ & $0 \%$ & $0 \%$ & $43 \%$ & $0 \%$ & $0 \%$ \\
\hline $\begin{array}{l}\text { Lawson et al. } \\
\qquad(2008)^{65}\end{array}$ & 34 & X-rt & 33 & 70.3 & 61 & $100 \%$ & $0 \%$ & $41 \%$ & $29 \%$ & $91 \%$ & $9 \%$ & $85 \%$ \\
\hline $\begin{array}{l}\text { Rusthoven } \\
\text { et al. } \\
(2008)^{67}\end{array}$ & 32 & X-rt & 33 & 69.3 & $\mathrm{nr}$ & $100 \%$ & $0 \%$ & $41 \%$ & $19 \%$ & $97 \%$ & $3 \%$ & $84 \%$ \\
\hline $\begin{array}{l}\text { Schoenfeld } \\
\text { et al. } \\
(2008)^{68}\end{array}$ & 64 & $\mathrm{X}-\mathrm{rt}$ & 42 & $67.5 / 72.0$ & $\mathrm{nr}$ & $54 \%$ & $0 \%$ & $42 \%$ & $20 \%^{*}$ & $70 \%$ & $5 \%$ & $63 \%$ \\
\hline $\begin{array}{l}\text { Garden et al. } \\
(2007)^{63}\end{array}$ & 51 & X-rt & 30 & $63.0-66.0$ & 54 & $10 \%$ & $0 \%$ & $0 \%$ & $0 \%$ & $67 \%$ & $4 \%$ & $53 \%$ \\
\hline $\begin{array}{l}\text { Lee et al. } \\
\qquad(2006)^{66}\end{array}$ & 41 & X-rt & $40 / 42$ & $70.0-72.0$ & 55 & $100 \%$ & $0 \%$ & $39 \%$ & $\mathrm{nr}$ & $90 \%$ & $5 \%$ & $85 \%$ \\
\hline $\begin{array}{l}\text { Yao et al. } \\
\qquad(2006)^{69}\end{array}$ & 66 & X-rt & $\mathrm{nr}$ & $60.0-74.0$ & 53 & $70 \%$ & $6 \%$ & $41 \%$ & $29 \%$ & $88 \%$ & $14 \%$ & $88 \%$ \\
\hline $\begin{array}{l}\text { Chao et al. } \\
(2004)^{61}\end{array}$ & 74 & X-rt & 35 & $66.0 / 70.0$ & 55 & $23 \%$ & $58 \%$ & $45 \%$ & $\mathrm{nr}$ & $84 \%$ & $\mathrm{nr}$ & $70 \%$ \\
\hline $\begin{array}{l}\text { Huang et al. } \\
(2003)^{64}\end{array}$ & 41 & X-rt & 33 & 70.0 & 55 & $73 \%$ & $7 \%$ & $17 \%$ & $7 \%$ & $76 \%$ & $5 \%$ & $68 \%$ \\
\hline
\end{tabular}


Appendix 4B. Characteristics of paranasal and sinonasal and mucosal malignant melanoma studies*

\begin{tabular}{|c|c|c|c|c|c|c|c|c|c|}
\hline & $N$ & Modality & $\begin{array}{l}\text { Total treatment dose } \\
(\mathrm{GyE})^{\dagger}\end{array}$ & $\mathrm{Age}^{\dagger}$ & $\% \mathrm{Ct}$ & $\begin{array}{l}\% \text { Operated } \\
\text { patients }\end{array}$ & $\% \mathrm{~T} 4$ & $\begin{array}{l}\% \\
\text { N3 }\end{array}$ & $\begin{array}{l}\text { \% Stage } \\
\text { III }^{\S}\end{array}$ \\
\hline \multicolumn{10}{|l|}{ Paranasal and sinonasal } \\
\hline Resto et al. Cs $(2008)^{72}$ & 20 & $\begin{array}{l}\text { P-rt + X- } \\
\text { rt }\end{array}$ & 67.6 & 50 & $33 \%$ & $100 \%$ & $\mathrm{nr}$ & $\mathrm{nr}$ & na \\
\hline Resto et al. Ps $(2008)^{72}$ & 50 & $\begin{array}{l}\text { P-rt + X- } \\
\text { rt }\end{array}$ & 75.6 & $50^{\ddagger}$ & $33 \%+$ & $100 \%$ & $\mathrm{nr}$ & $\mathrm{nr}$ & na \\
\hline Resto et al. Bo $(2008)^{72}$ & 32 & $\begin{array}{l}\text { P-rt + X- } \\
\text { rt }\end{array}$ & 75.4 & 50 & $33 \%$ & $0 \%$ & $\mathrm{nr}$ & $\mathrm{nr}$ & na \\
\hline Nishimura et al. $(2007)^{71}$ & 14 & P-rt & 65.0 & 56 & $29 \%$ & $50 \%$ & $\mathrm{nr}$ & $\mathrm{nr}$ & na \\
\hline Mizoe et al. $(2004)^{35}$ & 10 & C-rt & $48.6-64.8$ & $60^{\ddagger}$ & $6 \%$ & $33 \%$ & $\mathrm{nr}$ & $\mathrm{nr}$ & na \\
\hline Madani et al. $(2009)^{74}$ & 73 & $\mathrm{X}-\mathrm{rt}$ & 70.0 & 63 & $0 \%$ & $89 \%^{\ddagger}$ & $39 \%$ & $0 \%$ & na \\
\hline Daly et al. $(2007)^{73}$ & 36 & $\mathrm{X}-\mathrm{rt}$ & 70.0 & 57 & $22 \%$ & $89 \%$ & $69 \%$ & $0 \%$ & na \\
\hline \multicolumn{10}{|l|}{ Mucosal malignant melanoma } \\
\hline Mizoe et al. $(2009)^{34}$ & 100 & C-rt & 57.6 & $57^{\ddagger}$ & $0 \%$ & $\mathrm{nr}$ & na & na & $\mathrm{nr}$ \\
\hline Mizoe et al. $+\mathrm{Ct}(2009)^{76}$ & 57 & C-rt & 57.6 & 60 & $100 \%$ & $\mathrm{nr}$ & na & na & $\mathrm{nr}$ \\
\hline Meleti et al. $(2008)^{87}$ & 42 & $\mathrm{X}-\mathrm{rt}$ & 30.0 & 64 & $2 \%$ & $90 \%$ & na & na & $3 \%+$ \\
\hline Nakashima et al. $(2008)^{88}$ & 20 & $\mathrm{X}-\mathrm{rt}$ & 54.0 & 62 & $6 \%$ & $100 \%$ & na & na & $0 \%$ \\
\hline Wagner et al. $(2008)^{93}$ & 17 & $\mathrm{X}-\mathrm{rt}$ & 66.9 & 64 & $0 \%$ & $76 \%$ & na & na & $0 \%$ \\
\hline Huang et al. $(2007)^{81}$ & 15 & $\mathrm{X}-\mathrm{rt}$ & $\mathrm{nr}$ & 69 & $20 \%$ & $93 \%$ & na & na & $0 \%$ \\
\hline Krengli et al. $(2006)^{83}$ & 74 & $\mathrm{X}-\mathrm{rt}$ & 55.1 & 66 & $5 \%$ & $80 \%$ & na & na & $8 \%$ \\
\hline Bridger et al. $(2005)^{78}$ & 27 & $\mathrm{X}-\mathrm{rt}$ & $\mathrm{nr}$ & 66 & $0 \%$ & $100 \%$ & na & na & $\mathrm{nr}$ \\
\hline Temam et al. $(2005)^{92}$ & 69 & $\mathrm{X}-\mathrm{rt}$ & 64.9 & 58 & $0 \%$ & $100 \%$ & na & na & $0 \%$ \\
\hline Owens et al. $(2003)^{89}$ & 44 & $\mathrm{X}-\mathrm{rt}$ & $\mathrm{nr}$ & 56 & $0 \%$ & $100 \%$ & na & na & $\mathrm{nr}$ \\
\hline Yii et al. $(2003)^{94}$ & 89 & $\mathrm{X}-\mathrm{rt}$ & $\mathrm{nr}$ & 64 & $10 \%$ & $97 \%$ & na & na & $7 \%$ \\
\hline Patel et al. $(2002)^{90}$ & 59 & $\mathrm{X}-\mathrm{rt}$ & $\mathrm{nr}$ & 63 & $0 \%$ & $100 \%$ & na & na & $7 \%$ \\
\hline Loree et al. $(1999)^{84}$ & 28 & $\mathrm{X}-\mathrm{rt}$ & $\mathrm{nr}$ & $\mathrm{nr}$ & $18 \%$ & $61 \%$ & na & na & $4 \%$ \\
\hline Lund et al. $(1999)^{85}$ & 58 & $\mathrm{X}-\mathrm{rt}$ & $\mathrm{nr}$ & 64 & $16 \%$ & $100 \%$ & na & na & $0 \%$ \\
\hline $\begin{array}{l}\text { Manolidis and Donald } \\
(1997)^{86}\end{array}$ & 14 & $\mathrm{X}-\mathrm{rt}$ & $\mathrm{nr}$ & 71 & $0 \%$ & $86 \%$ & na & na & $\mathrm{nr}$ \\
\hline Kingdom and Kaplan (1995) & 10 & $\mathrm{X}-\mathrm{rt}$ & $\mathrm{nr}$ & $\mathrm{nr}$ & $0 \%$ & $100 \%$ & na & na & $\mathrm{nr}$ \\
\hline Guzzo et al. $(1993)^{80}$ & 48 & $\mathrm{X}-\mathrm{rt}$ & $\mathrm{nr}$ & 58 & $29 \%$ & $90 \%$ & na & na & $8 \%$ \\
\hline Shibuya et al. $(1993)^{91}$ & 28 & $\mathrm{X}-\mathrm{rt}$ & $\mathrm{nr}$ & $\mathrm{nr}$ & $0 \%$ & $0 \%$ & na & na & $0 \%$ \\
\hline Andersen et al. $(1992)^{77}$ & 26 & $\mathrm{X}-\mathrm{rt}$ & 54.0 & 65 & $0 \%$ & $77 \%$ & na & na & $4 \%$ \\
\hline Gilligan and Slevin $(1991)^{79}$ & 28 & $\mathrm{X}-\mathrm{rt}$ & $45.0-55.0$ & 65 & $0 \%$ & $0 \%$ & na & na & $\mathrm{nr}$ \\
\hline
\end{tabular}

Appendix 4C. Characteristics of adenoid cystic carcinoma studies*

\begin{tabular}{|c|c|c|c|c|c|c|c|c|c|}
\hline & $N$ & Modality & $\begin{array}{l}\text { Total treatment dose } \\
(\mathrm{GyE})^{\dagger}\end{array}$ & Age $^{\dagger}$ & $\begin{array}{l}\% \\
\mathrm{Ct}\end{array}$ & $\begin{array}{l}\% \text { Operated } \\
\text { patients }\end{array}$ & $\begin{array}{l}\% \\
\mathrm{~T} 4\end{array}$ & $\begin{array}{l}\% \\
\mathrm{~N} 3\end{array}$ & $\begin{array}{l}\text { \% Stage } \\
\text { IV }\end{array}$ \\
\hline \multicolumn{10}{|l|}{ Adenoid cystic carcinoma } \\
\hline Pommier et al. $(2006)^{98}$ & 23 & $\begin{array}{l}\text { P-rt + X- } \\
\text { rt }\end{array}$ & $73.3 / 76.4$ & 46 & $4 \%$ & $52 \%$ & $\mathrm{nr}$ & $0 \%$ & $\mathrm{nr}$ \\
\hline Mizoe et al. $(2009)^{34}$ & 107 & C-rt & 57.6 & $57^{\ddagger}$ & $\mathrm{nr}$ & $\mathrm{nr}$ & $\mathrm{nr}$ & $\mathrm{nr}$ & $\mathrm{nr}$ \\
\hline Munter et al. $(2009)^{97}$ & 59 & $\begin{array}{l}\mathrm{C}-\mathrm{rt}+\mathrm{X}- \\
\mathrm{rt}\end{array}$ & 72.0 & 52 & $\mathrm{nr}$ & $\mathrm{nr}$ & $\mathrm{nr}$ & $\mathrm{nr}$ & $\mathrm{nr}$ \\
\hline Agarwal et al. (2008) ${ }^{99}$ & 76 & $\mathrm{X}-\mathrm{rt}$ & 56.0 & $\mathrm{nr}$ & $0 \%$ & $97 \%$ & $54 \%$ & $\mathrm{nr}$ & $59 \%$ \\
\hline Gomez et al. $(2008)^{104}$ & 59 & $\mathrm{X}-\mathrm{rt}$ & 63.0 & 52 & $10 \%$ & $92 \%$ & $34 \%$ & $\mathrm{nr}$ & $\mathrm{nr}$ \\
\hline Leonetti et al. $(2008)^{113}$ & 16 & $\mathrm{X}-\mathrm{rt}$ & $51.0-60.0$ & 47 & $0 \%$ & $100 \%$ & $\mathrm{nr}$ & $\mathrm{nr}$ & $\mathrm{nr}$ \\
\hline Da Cruz Perez et al. $(2006)^{102}$ & 18 & $\mathrm{X}-\mathrm{rt}$ & 53.6 & 39 & $17 \%$ & $61 \%$ & $\mathrm{nr}$ & $\mathrm{nr}$ & $\mathrm{nr}$ \\
\hline Rhee et al. $(2006)^{116}$ & 35 & $\mathrm{X}-\mathrm{rt}$ & $\mathrm{nr}$ & 47 & $9 \%$ & $77 \%$ & $49 \%$ & $\mathrm{nr}$ & $\mathrm{nr}$ \\
\hline $\begin{array}{l}\text { Bhattacharyya and Fried } \\
(2005)^{101}\end{array}$ & 18 & $\mathrm{X}-\mathrm{rt}$ & $\mathrm{nr}$ & 59 & $\mathrm{nr}$ & $\mathrm{nr}$ & $\mathrm{nr}$ & $\mathrm{nr}$ & $\mathrm{nr}$ \\
\hline Mendenhall et al. (2004) & 101 & $\mathrm{X}-\mathrm{rt}$ & $10.5-79.2$ & 58 & $2 \%$ & $58 \%$ & $44 \%$ & $0 \%$ & $45 \%$ \\
\hline Silverman et al. $(2004)^{117}$ & 75 & $\mathrm{X}-\mathrm{rt}$ & $\mathrm{nr}$ & 52 & $0 \%$ & $100 \%$ & $31 \%$ & $0 \%$ & $31 \%$ \\
\hline
\end{tabular}


Appendix 4C (continued)

\begin{tabular}{|c|c|c|c|c|c|c|c|c|c|}
\hline & $N$ & Modality & $\begin{array}{l}\text { Total treatment dose } \\
(\mathrm{GyE})^{\dagger}\end{array}$ & $\mathrm{Age}^{\dagger}$ & $\begin{array}{l}\% \\
\mathrm{Ct}\end{array}$ & $\begin{array}{l}\% \text { Operated } \\
\text { patients }\end{array}$ & $\begin{array}{l}\% \\
\mathrm{~T} 4\end{array}$ & $\begin{array}{l}\% \\
\text { N3 }\end{array}$ & $\begin{array}{l}\text { \% Stage } \\
\text { IV }\end{array}$ \\
\hline Hsu et al. $(2003)^{108}$ & 25 & X-rt & $\mathrm{nr}$ & 50 & $0 \%$ & $100 \%$ & $\mathrm{nr}$ & $\mathrm{nr}$ & $12 \%$ \\
\hline Harbo et al. $(2002)^{106}$ & 26 & $\mathrm{X}-\mathrm{rt}$ & $\mathrm{nr}$ & $64^{*}$ & $0 \%$ & $49 \%$ & $7 \%$ & $2 \%$ & $36 \%$ \\
\hline Khan et al. $(2001)^{111}$ & 68 & $\mathrm{X}-\mathrm{rt}$ & $\mathrm{nr}$ & 52 & $3 \%$ & $87 \%$ & $22 \%$ & $\mathrm{nr}$ & $31 \%$ \\
\hline Takagi et al. $(2001)^{119}$ & 20 & $\mathrm{X}-\mathrm{rt}$ & $40.0-65.0$ & 59 & $35 \%$ & $85 \%$ & $\mathrm{nr}$ & $\mathrm{nr}$ & $\mathrm{nr}$ \\
\hline Avery et al. $(2000)^{100}$ & 15 & $\mathrm{X}-\mathrm{rt}$ & $\mathrm{nr}$ & 53 & $7 \%$ & $100 \%$ & $\mathrm{nr}$ & $\mathrm{nr}$ & $33 \%$ \\
\hline Hosokawa et al. $(1992)^{107}$ & 41 & $\mathrm{X}-\mathrm{rt}$ & $40.0-70.0$ & 58 & $0 \%$ & $79 \%$ & $\mathrm{nr}$ & $\mathrm{nr}$ & $\mathrm{nr}$ \\
\hline Spiro and Huvos $(1992)^{118}$ & 184 & $\mathrm{X}-\mathrm{rt}$ & $\mathrm{nr}$ & 57 & $0 \%$ & $95 \%$ & $\mathrm{nr}$ & $\mathrm{nr}$ & $12 \%$ \\
\hline
\end{tabular}

Only characteristics of studies included in meta-analyses were reported. †Median/mean value. $¥$ Figures are for the whole study sample not only for this subgroup, §According to Ballantyne's staging system.

Abbreviations: $\mathrm{X}$-rt $=$ photon radiotherapy, P-rt $=$ proton radiotherapy, C-rt $=$ carbon-ion radiotherapy, Cs $=$ complete surgery, Ps $=$ partial surgery, Bo $=$ biopsy only, $\mathrm{Ct}=$ chemotherapy, $\mathrm{nr}=$ not reported, $\mathrm{na}=$ not applicable.

\section{References}

1. Ferlay J, Autier P, Boniol M, Heanue M, Colombet M, Boyle P. Estimates of the cancer incidence and mortality in Europe in 2006. Ann Oncol 2007;18:581-92.

2. Baujat B, Audry H, Bourhis J, et al. Chemotherapy in locally advanced nasopharyngeal carcinoma: an individual patient data meta-analysis of eight randomized trials and 1753 patients. Int J Radiat Oncol Biol Phys 2006;64: 47-56.

3. Bourhis J, Overgaard J, Audry $\mathrm{H}$, et al. Hyperfractionated or accelerated radiotherapy in head and neck cancer: a meta-analysis. Lancet 2006;368: 843-54.

4. Pignon JP, le Maitre A, Maillard E, Bourhis J. Meta-analysis of chemotherapy in head and neck cancer (MACH-NC): an update on 93 randomised trials and 17 . 346 patients. Radiother Oncol 2009;92:4-14.

5. Duke RL, Campbell BH, Indresano AT, et al. Dental status and quality of life in long-term head and neck cancer survivors. Laryngoscope 2005;115:678-83.

6. Hammerlid E, Silander E, Hornestam L, Sullivan M. Health-related quality of life three years after diagnosis of head and neck cancer - a longitudinal study. Head Neck 2001;23:113-25.

7. Jensen $A B$, Hansen $O$, Jorgensen $K$, Bastholt L. Influence of late side-effects upon daily life after radiotherapy for laryngeal and pharyngeal cancer. Acta Oncol 1994;33:487-91.

8. Langendijk JA, Doornaert P, Verdonck-de Leeuw IM, Leemans CR, Aaronson NK, Slotman BJ. Impact of late treatment-related toxicity on quality of life among patients with head and neck cancer treated with radiotherapy. J Clin Oncol 2008;26:3770-6.

9. List MA, Bilir SP. Functional outcomes in head and neck cancer. Semin Radiat Oncol 2004; 14:178-89.

10. Durante M, Loeffler JS. Charged particles in radiation oncology. Nat Rev Clin Oncol 2010;7:37-43.

11. Glimelius B, Ask A, Bjelkengren G, et al. Number of patients potentially eligible for proton therapy. Acta Oncol 2005;44:836-49.

12. Palm A, Johansson KA. A review of the impact of photon and proton external beam radiotherapy treatment modalities on the dose distribution in field and out-of-field; implications for the long-term morbidity of cancer survivors. Acta Oncol 2007;46:462-73.

13. Brada M, Pijls-Johannesma M, De Ruysscher D. Proton therapy in clinical practice: current clinical evidence. J Clin Oncol 2007;25:965-70.

14. Jereczek-Fossa BA, Krengli M, Orecchia R. Particle beam radiotherapy for head and neck tumors: radiobiological basis and clinical experience. Head Neck 2006;28:750-60.

15. Lodge M, Pijls-Johannesma M, Stirk L, Munro AJ, De Ruysscher D, Jefferson T. A systematic literature review of the clinical and cost-effectiveness of hadron therapy in cancer. Radiother Oncol 2007;83:110-22.

16. Chan AW, Liebsch NJ. Proton radiation therapy for head and neck cancer. J Surg Oncol 2008;97:697-700.

17. Ask A, Bjork-Eriksson T, Zackrisson B, Blomquist E, Glimelius B. The potential of proton beam radiation therapy in head and neck cancer. Acta Oncol 2005;44:876-80

18. Schulz-Ertner D, Jakel O, Schlegel W. Radiation therapy with charged particles. Semin Radiat Oncol 2006;16:249-59.

19. Schulz-Ertner D, Tsujii H. Particle radiation therapy using proton and heavier ion beams. J Clin Oncol 2007;25:953-64

20. Brada M, Pijls-Johannesma M, De Ruysscher D. Current clinical evidence for proton therapy. Cancer J 2009;15:319-24.

21. Pijls-Johannesma M, Pommier P, Lievens Y. Cost-effectiveness of particle therapy: current evidence and future needs. Radiother Oncol 2008;89:127-34

22. Glimelius B, Isacsson U, Blomquist E, Grusell E, Jung B, Montelius A. Potentia gains using high-energy protons for therapy of malignant tumours. Acta Oncol 1999;38:137-45.
23. Richardson WS, Wilson MC, Nishikawa J, Hayward RS. The well-built clinical question: a key to evidence-based decisions. ACP J Club 1995;123:A12-3.

24. Feuvret L, Noel G, Mazeron JJ, Bey P. Conformity index: a review. Int J Radiat Oncol Biol Phys 2006;64:333-42.

25. Mayo C, Martel MK, Marks LB, Flickinger J, Nam J, Kirkpatrick J. Radiation dose-volume effects of optic nerves and chiasm. Int J Radiat Oncol Biol Phys 2010;76:S28-35.

26. Deasy JO, Moiseenko V, Marks L, Chao KS, Nam J, Eisbruch A. Radiotherapy dose-volume effects on salivary gland function. Int J Radiat Oncol Biol Phys 2010;76:S58-63.

27. Caudell JJ, Burnett OL, Schaner PE, Bonner JA, Duan J. Comparison of methods to reduce dose to swallowing-related structures in head and neck cancer. Int J Radiat Oncol Biol Phys 2010;77:462-7.

28. Rancati T, Schwarz M, Allen AM, et al. Radiation dose-volume effects in the larynx and pharynx. Int J Radiat Oncol Biol Phys 2010;76:S64-9.

29. Moore DS, McCabe GP, Craig BA. Introduction to the practice of statistics. 6th ed. W.H. Freeman Company; 2009.

30. Cantor AB. Projecting the standard error of the Kaplan-Meier estimator. Stat Med 2001:20:2091-7.

31. Peto R, Pike MC, Armitage P, et al. Design and analysis of randomized clinical trials requiring prolonged observation of each patient: II analysis and examples. Br Journal of Cancer 1973;35:1-39.

32. Thompson SG, Higgins JP. How should meta-regression analyses be undertaken and interpreted? Stat Med 2002;21:1559-73.

33. Stroup DF, Berlin JA, Morton SC, et al. Meta-analysis of observational studies in epidemiology: a proposal for reporting. Meta-analysis of Observational Studies in Epidemiology (MOOSE) group. JAMA 2000;283:2008-12.

34. Mizoe JE, Hasegawa A, Bessho H, Jingu K, Kakimoto Y. Head and neck tumors. In: Proceedings of NIRS-ETOILE: joint symposium 2009 on carbon ion radiotherapy. Lyon; 2009.

35. Mizoe JE, Tsujii H, Kamada $\mathrm{T}$, et al. Dose escalation study of carbon ion radiotherapy for locally advanced head-and-neck cancer. Int J Radiat Oncol Biol Phys 2004;60:358-64.

36. Tokuuye K, Akine Y, Kagei K, et al. Proton therapy for head and neck malignancies at Tsukuba. Strahlenther Onkol 2004;180:96-101.

37. Milano MT, Vokes EE, Kao J, et al. Intensity-modulated radiation therapy in advanced head and neck patients treated with intensive chemoradiotherapy: preliminary experience and future directions. Int J Oncol 2006;28:1141-51.

38. Monroe AT, Young JA, Huff JD, Ernster JA, White GA, Peddada AV. Accelerated fractionation head and neck intensity-modulated radiation therapy and concurrent chemotherapy in the community setting: safety and efficacy considerations. Head Neck 2009;31:1144-51.

39. Rades D, Fehlauer F, Wroblesky J, Albers D, Schild SE, Schmidt R. Prognostic factors in head-and-neck cancer patients treated with surgery followed by intensity-modulated radiotherapy (IMRT), 3D-conformal radiotherapy, or conventional radiotherapy. Oral Oncol 2007;43:535-43.

40. Studer G, Furrer K, Davis BJ, et al. Postoperative IMRT in head and neck cancer. Radiat Oncol 2006;1:40.

41. Seung S, Bae J, Solhjem M, et al. Intensity-modulated radiotherapy for headand-neck cancer in the community setting. Int J Radiat Oncol Biol Phys 2008;72:1075-81

42. Lauve A, Morris M, Schmidt-Ullrich R, et al. Simultaneous integrated boost intensity-modulated radiotherapy for locally advanced head-and-neck squamous cell carcinomas: II - clinical results. Int J Radiat Oncol Biol Phys 2004;60:374-87.

43. Nangia S, Chufal KS, Tyagi A, Bhatnagar A, Mishra M, Ghosh D. Selective nodal irradiation for head and neck cancer using intensity-modulated radiotherapy: application of RTOG consensus guidelines in routine clinical practice. Int J Radiat Oncol Biol Phys; 2009. 
44. Saba NF, Edelman S, Tighiouart M, et al. Concurrent chemotherapy with intensity-modulated radiation therapy for locally advanced squamous cell carcinoma of the larynx and oropharynx: a retrospective single-institution analysis. Head Neck 2009;31:1447-55.

45. Chan AW, Liebsch LJ, Deschler DG, et al. Proton radiotherapy for T4 nasopharyngeal carcinoma. J Clin Oncol (Meeting Abstracts) 2004;22:5574.

46. Chong Z. Improved local control with intensity modulated radiation therapy in patients with nasopharyngeal carcinoma. Int J Radiat Oncol Biol Phys 2004;60:S317.

47. Fang FM, Chien CY, Tsai WL, et al. Quality of life and survival outcome for patients with nasopharyngeal carcinoma receiving three-dimensional conformal radiotherapy vs. intensity-modulated radiotherapy - a longitudinal study. Int J Radiat Oncol Biol Phys 2008;72:356-64.

48. Kam MK, Teo PM, Chau RM, et al. Treatment of nasopharyngeal carcinoma with intensity-modulated radiotherapy: the Hong Kong experience. Int J Radiat Oncol Biol Phys 2004;60:1440-50.

49. Kim $\mathrm{K}, \mathrm{Wu} \mathrm{HG}, \mathrm{Kim} \mathrm{HJ}$, et al. Intensity-modulated radiation therapy with simultaneous integrated boost technique following neoadjuvant chemotherapy for locoregionally advanced nasopharyngeal carcinoma. Head Neck 2009;31:1121-8.

50. Koom WS, Kim TH, Shin KH, et al. SMART (simultaneous modulated accelerated radiotherapy) for locally advanced nasopharyngeal carcinomas. Head Neck 2008;30:159-69.

51. Kwong DL, Pow EH, Sham JS, et al. Intensity-modulated radiotherapy for earlystage nasopharyngeal carcinoma: a prospective study on disease control and preservation of salivary function. Cancer 2004;101:1584-93.

52. Lee N, Harris J, Garden AS, et al. Intensity-modulated radiation therapy with or without chemotherapy for nasopharyngeal carcinoma: radiation therapy oncology group phase II trial 0225. J Clin Oncol 2009;27:3684-90.

53. Lee $\mathrm{N}$, Xia $\mathrm{P}$, Quivey JM, et al. Intensity-modulated radiotherapy in the treatment of nasopharyngeal carcinoma: an update of the UCSF experience. Int J Radiat Oncol Biol Phys 2002;53:12-22.

54. Lin S, Pan J, Han L, Zhang X, Liao X, Lu JJ. Nasopharyngeal carcinoma treated with reduced-volume intensity-modulated radiation therapy: report on the 3year outcome of a prospective series. Int $J$ Radiat Oncol Biol Phys 2009;75:1071-8

55. Nishimura Y, Shibata T, Nakamatsu K, et al. A two-step intensity-modulated radiation therapy method for nasopharyngeal cancer: the Kinki University experience. Jpn J Clin Oncol 2009;40:130-8.

56. Tham IW, Hee SW, Yeo RM, et al. Treatment of nasopharyngeal carcinoma using intensity-modulated radiotherapy - The National Cancer Centre Singapore experience. Int J Radiat Oncol Biol Phys 2009;75:1481-6.

57. Wolden SL, Chen WC, Pfister DG, Kraus DH, Berry SL, Zelefsky MJ. Intensitymodulated radiation therapy (IMRT) for nasopharynx cancer: update of the Memorial Sloan-Kettering experience. Int J Radiat Oncol Biol Phys 2006;64:57-62.

58. Wong FC, Ng AW, Lee VH, et al. Whole-field simultaneous integrated-boost intensity-modulated radiotherapy for patients with nasopharyngeal carcinoma. Int J Radiat Oncol Biol Phys 2009;76:138-45.

59. Zheng J, Wang G, Yang GY, et al. Induction chemotherapy with nedaplatin with 5-FU followed by intensity-modulated radiotherapy concurrent with chemotherapy for locoregionally advanced nasopharyngeal carcinoma. Jpn J Clin Oncol 2010 [Epub ahead of print].

60. Slater JD, Yonemoto LT, Mantik DW, et al. Proton radiation for treatment of cancer of the oropharynx: early experience at Loma Linda University Medical Center using a concomitant boost technique. Int J Radiat Oncol Biol Phys 2005;62:494-500.

61. Chao KS, Ozyigit G, Blanco AI, et al. Intensity-modulated radiation therapy for oropharyngeal carcinoma: impact of tumor volume. Int J Radiat Oncol Biol Phys 2004;59:43-50.

62. Eisbruch A, Harris J, Garden AS, et al. Multi-institutional trial of accelerated hypofractionated intensity-modulated radiation therapy for early-stage oropharyngeal cancer (RTOG 00-22). Int J Radiat Oncol Biol Phys 2009.

63. Garden AS, Morrison WH, Wong PF, et al. Disease-control rates following intensity-modulated radiation therapy for small primary oropharyngeal carcinoma. Int J Radiat Oncol Biol Phys 2007;67:438-44.

64. Huang $K$, Lee $N$, Xia $P$, et al. Intensity-modulated radiotherapy in the treatment of oropharyngeal carcinoma: a single institutional experience. Int J Radiat Oncol Biol Phys 2003;57:S302.

65. Lawson JD, Otto K, Chen A, Shin DM, Davis L, Johnstone PA. Concurrent platinum-based chemotherapy and simultaneous modulated accelerated radiation therapy for locally advanced squamous cell carcinoma of the tongue base. Head Neck 2008;30:327-35.

66. Lee NY, de Arruda FF, Puri DR, et al. A comparison of intensity-modulated radiation therapy and concomitant boost radiotherapy in the setting of concurrent chemotherapy for locally advanced oropharyngeal carcinoma. Int J Radiat Oncol Biol Phys 2006;66:966-74.

67. Rusthoven KE, Raben D, Ballonoff A, Kane M, Song JI, Chen C. Effect of radiation techniques in treatment of oropharynx cancer. Laryngoscope 2008;118:635-9.

68. Schoenfeld GO, Amdur RJ, Morris CG, Li JG, Hinerman RW, Mendenhall WM. Patterns of failure and toxicity after intensity-modulated radiotherapy for head and neck cancer. Int J Radiat Oncol Biol Phys 2008;71:377-85.

69. Yao M, Nguyen T, Buatti JM, et al. Changing failure patterns in oropharyngeal squamous cell carcinoma treated with intensity modulated radiotherapy and implications for future research. Am J Clin Oncol 2006;29:606-12.
70. Daly ME, Le QT, Maxim PG, et al. Intensity-modulated radiotherapy in the treatment of oropharyngeal cancer: clinical outcomes and patterns of failure. Int J Radiat Oncol Biol Phys 2010;76:1339-46.

71. Nishimura H, Ogino T, Kawashima M, et al. Proton-beam therapy for olfactory neuroblastoma. Int J Radiat Oncol Biol Phys 2007;68:758-62.

72. Resto VA, Chan AW, Deschler DG, Lin DT. Extent of surgery in the management of locally advanced sinonasal malignancies. Head Neck 2008;30:222-9.

73. Daly ME, Chen AM, Bucci MK, et al. Intensity-modulated radiation therapy for malignancies of the nasal cavity and paranasal sinuses. Int J Radiat Oncol Bio Phys 2007;67:151-7.

74. Madani I, Bonte K, Vakaet L, Boterberg T, De Neve W. Intensity-modulated radiotherapy for sinonasal tumors: Ghent University Hospital update. Int Radiat Oncol Biol Phys 2009;73:424-32.

75. Weber DC, Chan AW, Lessell S, et al. Visual outcome of accelerated fractionated radiation for advanced sinonasal malignancies employing photons/protons. Radiother Oncol 2006;81:243-9.

76. Mizoe JE, Hasegawa A, Bessho H, Jingu K, Kakimoto Y. Phase II clinical trial for mucosal malignant melanoma of the head and neck combined with chemotherapy (protocol 0007). In: Proceedings of NIRS-ETOILE: joint symposium 2009 on carbon ion radiotherapy. Lyon; 2009.

77. Andersen LJ, Berthelsen A, Hansen HS. Malignant melanoma of the upper respiratory tract and the oral cavity. J Otolaryngol 1992;21:180-5.

78. Bridger AG, Smee D, Baldwin MA, Kwok B, Bridger GP. Experience with mucosal melanoma of the nose and paranasal sinuses. ANZ J Surg 2005;75:192-7.

79. Gilligan D, Slevin NJ. Radical radiotherapy for 28 cases of mucosal melanoma in the nasal cavity and sinuses. Br J Radiol 1991;64:1147-50.

80. Guzzo M, Grandi C, Licitra L, Podrecca S, Cascinelli N, Molinari R. Mucosal malignant melanoma of head and neck: forty-eight cases treated at Istituto Nazionale Tumori of Milan. Eur J Surg Oncol 1993;19:316-9.

81. Huang SF, Liao CT, Kan CR, Chen IH. Primary mucosal melanoma of the nasal cavity and paranasal sinuses: 12 years of experience. $J$ Otolaryngol 2007;36:124-9.

82. Kingdom TT, Kaplan MJ. Mucosal melanoma of the nasal cavity and paranasa sinuses. Head Neck 1995;17:184-9.

83. Krengli M, Masini L, Kaanders JH, et al. Radiotherapy in the treatment of mucosal melanoma of the upper aerodigestive tract: analysis of 74 cases. A Rare Cancer Network study. Int J Radiat Oncol Biol Phys 2006;65:751-9.

84. Loree TR, Mullins AP, Spellman J, North Jr JH, Hicks Jr WL. Head and neck mucosal melanoma: a 32-year review. Ear Nose Throat J 1999;78:372-5.

85. Lund VJ, Howard DJ, Harding L, Wei WI. Management options and survival in malignant melanoma of the sinonasal mucosa. Laryngoscope 1999;109:208-11.

86. Manolidis S, Donald PJ. Malignant mucosal melanoma of the head and neck: review of the literature and report of 14 patients. Cancer 1997;80:1373-86.

87. Meleti M, Leemans CR, de Bree R, Vescovi P, Sesenna E, van der Waal I. Head and neck mucosal melanoma: experience with 42 patients, with emphasis on the role of postoperative radiotherapy. Head Neck 2008;30:1543-51.

88. Nakashima JP, Viegas CM, Fassizoli AL, et al. Postoperative adjuvant radiation therapy in the treatment of primary head and neck mucosal melanomas. ORLJ Otorhinolaryngol Relat Spec 2008;70:344-51.

89. Owens JM, Roberts DB, Myers JN. The role of postoperative adjuvant radiation therapy in the treatment of mucosal melanomas of the head and neck region. Arch Otolaryngol Head Neck Surg 2003;129:864-8.

90. Patel SG, Prasad ML, Escrig M, et al. Primary mucosal malignant melanoma of the head and neck. Head Neck 2002;24:247-57.

91. Shibuya H, Takeda M, Matsumoto S, Hoshina M, Suzuki S, Takagi M. The efficacy of radiation therapy for a malignant melanoma in the mucosa of the upper jaw: an analytic study. Int J Radiat Oncol Biol Phys 1993;25:35-9.

92. Temam S, Mamelle G, Marandas $P$, et al. Postoperative radiotherapy for primary mucosal melanoma of the head and neck. Cancer 2005;103:313-9.

93. Wagner M, Morris CG, Werning JW, Mendenhall WM. Mucosal melanoma of the head and neck. Am J Clin Oncol 2008;31:43-8.

94. Yii NW, Eisen T, Nicolson M, et al. Mucosal malignant melanoma of the head and neck: the Marsden experience over half a century. Clin Oncol ( $R$ Coll Radiol) 2003;15:199-204.

95. Yanagi T, Mizoe JE, Hasegawa A, et al. Mucosal malignant melanoma of the head and neck treated by carbon ion radiotherapy. Int J Radiat Oncol Biol Phys 2009;74:15-20.

96. Schulz-Ertner D, Nikoghosyan A, Didinger B, et al. Therapy strategies for locally advanced adenoid cystic carcinomas using modern radiation therapy techniques. Cancer 2005;104:338-44.

97. Munter M, Umathum V, Nikoghosyan A, et al. Combination of intensity modulated radiation therapy (IMRT) and a carbon ion boost for subtotal resected or inoperable adenoid cystic carcinomas (ACC's) of the head and neck region. Heidelberg; 2009 [PTCOG 48].

98. Pommier P, Liebsch NJ, Deschler DG, et al. Proton beam radiation therapy for skull base adenoid cystic carcinoma. Arch Otolaryngol Head Neck Surg 2006;132:1242-9.

99. Agarwal JP, Jain S, Gupta T, et al. Intraoral adenoid cystic carcinoma: prognostic factors and outcome. Oral Oncol 2008;44:986-93.

100. Avery CM, Moody AB, McKinna FE, Taylor J, Henk JM, Langdon JD. Combined treatment of adenoid cystic carcinoma of the salivary glands. Int J Ora Maxillofac Surg 2000;29:277-9. 
101. Bhattacharyya N, Fried MP. Determinants of survival in parotid gland carcinoma: a population-based study. Am J Otolaryngol 2005;26:39-44.

102. Da Cruz Perez DE, Pires FR, Lopes MA, de Almeida OP, Kowalski LP. Adenoid cystic carcinoma and mucoepidermoid carcinoma of the maxillary sinus: report of a 44-year experience of 25 cases from a single institution. J Oral Maxillofac Surg 2006;64:1592-7.

103. Garden AS, Weber RS, Morrison WH, Ang KK, Peters LJ. The influence of positive margins and nerve invasion in adenoid cystic carcinoma of the head and neck treated with surgery and radiation. Int J Radiat Oncol Biol Phys 1995;32:619-26.

104. Gomez DR, Hoppe BS, Wolden SL, et al. Outcomes and prognostic variables in adenoid cystic carcinoma of the head and neck: a recent experience. Int J Radiat Oncol Biol Phys 2008;70:1365-72.

105. Gurney TA, Eisele DW, Weinberg V, Shin E, Lee N. Adenoid cystic carcinoma of the major salivary glands treated with surgery and radiation. Laryngoscope 2005;115:1278-82.

106. Harbo G, Bundgaard T, Pedersen D, Sogaard H, Overgaard J. Prognostic indicators for malignant tumours of the parotid gland. Clin Otolaryngol Allied Sci 2002;27:512-6.

107. Hosokawa Y, Ohmori K, Kaneko M, et al. Analysis of adenoid cystic carcinoma treated by radiotherapy. Oral Surg Oral Med Oral Pathol 1992;74:251-5.

108. Hsu HC, Huang EY, Wang CJ. Postoperative adjuvant radiotherapy for adenoid cystic carcinoma of the head and neck: treatment results and prognostic factors. Chang Gung Med J 2003;26:646-53.

109. Huber PE, Debus J, Latz D, et al. Radiotherapy for advanced adenoid cystic carcinoma: neutrons, photons or mixed beam? Radiother Oncol 2001;59:161-7.

110. Iseli TA, Karnell LH, Graham SM, et al. Role of radiotherapy in adenoid cystic carcinoma of the head and neck. J Laryngol Otol 2009;1-8.

111. Khan AJ, DiGiovanna MP, Ross DA, et al. Adenoid cystic carcinoma: retrospective clinical review. Int J Cancer 2001;96:149-58.

112. Kokemueller H, Eckardt A, Brachvogel P, Hausamen JE. Adenoid cystic carcinoma of the head and neck - a 20 years experience. Int $J$ Oral Maxillofac Surg 2004;33:25-31.

113. Leonetti JP, Marzo SJ, Agarwal N. Adenoid cystic carcinoma of the parotid gland with temporal bone invasion. Otol Neurotol 2008;29:545-8.

114. Mendenhall WM, Morris CG, Amdur RJ, Werning JW, Hinerman RW, Villaret DB. Radiotherapy alone or combined with surgery for adenoid cystic carcinoma of the head and neck. Head Neck 2004;26:154-62.

115. Rapidis AD, Givalos N, Gakiopoulou H, et al. Adenoid cystic carcinoma of the head and neck. Clinicopathological analysis of 23 patients and review of the literature. Oral Oncol 2005;41:328-35.

116. Rhee CS, Won TB, Lee $\mathrm{CH}$, et al. Adenoid cystic carcinoma of the sinonasal tract: treatment results. Laryngoscope 2006;116:982-6.

117. Silverman DA, Carlson TP, Khuntia D, Bergstrom RT, Saxton J, Esclamado RM. Role for postoperative radiation therapy in adenoid cystic carcinoma of the head and neck. Laryngoscope 2004;114:1194-9.

118. Spiro RH, Huvos AG. Stage means more than grade in adenoid cystic carcinoma. Am J Surg 1992;164:623-8.

119. Takagi D, Fukuda S, Furuta Y, et al. Clinical study of adenoid cystic carcinoma of the head and neck. Auris Nasus Larynx 2001;28(Suppl.):S99-S102.

120. Therkildsen MH, Christensen M, Andersen LJ, Schiodt T, Hansen HS. Salivary gland carcinomas-prognostic factors. Acta Oncol 1998;37:701-13.

121. Amirul Islam M, Yanagi T, Mizoe JE, Mizuno H, Tsujii H. Comparative study of dose distribution between carbon ion radiotherapy and photon radiotherapy for head and neck tumor. Radiat Med 2008;26:415-21.
122. Cozzi L, Fogliata A, Lomax A, Bolsi A. A treatment planning comparison of 3D conformal therapy, intensity modulated photon therapy and proton therapy for treatment of advanced head and neck tumours. Radiother Oncol 2001;61:287-97.

123. Johansson J, Blomquist E, Montelius A, Isacsson U, Glimelius B. Potential outcomes of modalities and techniques in radiotherapy for patients with hypopharyngeal carcinoma. Radiother Oncol 2004;72:129-38.

124. Mock U, Georg D, Bogner J, Auberger T, Potter R. Treatment planning comparison of conventional, 3D conformal, and intensity-modulated photon (IMRT) and proton therapy for paranasal sinus carcinoma. Int J Radiat Oncol Biol Phys 2004;58:147-54.

125. Steneker M, Lomax A, Schneider U. Intensity modulated photon and proton therapy for the treatment of head and neck tumors. Radiother Oncol 2006;80:263-7.

126. Taheri-Kadkhoda Z, Bjork-Eriksson $\mathrm{T}$, Nill S, et al. Intensity-modulated radiotherapy of nasopharyngeal carcinoma: a comparative treatment planning study of photons and protons. Radiat Oncol 2008;3:4.

127. Van de Water T, Lomax A, Bijl H, et al. Comparative treatment planning study between scanned intensity modulated proton therapy and photon therapy in complex oropharyngeal carcinoma. ESTRO. Göteborg; 2008.

128. Widesott L, Pierelli A, Fiorino C, et al. Intensity-modulated proton therapy versus helical tomotherapy in nasopharynx cancer: planning comparison and NTCP evaluation. Int J Radiat Oncol Biol Phys 2008;72:589-96.

129. Krengli M, Jereczek-Fossa BA, Kaanders JH, Masini L, Beldi D, Orecchia R. What is the role of radiotherapy in the treatment of mucosal melanoma of the head and neck? Crit Rev Oncol Hematol 2008;65:121-8.

130. Overgaard J. The role of radiotherapy in recurrent and metastatic malignant melanoma: a clinical radiobiological study. Int J Radiat Oncol Biol Phys 1986;12:867-72.

131. Blettner M, Sauerbrei W, Schlehofer B, Scheuchenpflug T, Friedenreich C. Traditional reviews, meta-analyses and pooled analyses in epidemiology. Int J Epidemiol 1999;28:1-9.

132. National Institute for Health and Clinical Excellence (NICE). Guide to the methods of technology appraisal. London: NICE; 2008.

133. PTCOG. Statistics of patients treated in hadron therapy centers worldwide; 2009. Available from: http://ptcog.web.psi.ch/patient_statistics.html [accessed 2009].

134. Sayed SI, Elmiyeh B, Rhys-Evans P, et al. Quality of life and outcomes research in head and neck cancer: a review of the state of the discipline and likely future directions. Cancer Treat Rev 2009.

135. Goitein M. Trials and tribulations in charged particle radiotherapy. Radiother Oncol 2010;95:23-31.

136. Eisbruch A, Ten Haken RK, Kim HM, Marsh LH, Ship JA. Dose, volume, and function relationships in parotid salivary glands following conformal and intensity-modulated irradiation of head and neck cancer. Int J Radiat Oncol Biol Phys 1999;45:577-87.

137. Roesink JM, Moerland MA, Hoekstra A, Van Rijk PP, Terhaard CH. Scintigraphic assessment of early and late parotid gland function after radiotherapy for head-and-neck cancer: a prospective study of dose-volume response relationships. Int J Radiat Oncol Biol Phys 2004;58:1451-60.

138. Semenenko VA, Li XA. Lyman-Kutcher-Burman NTCP model parameters for radiation pneumonitis and xerostomia based on combined analysis of published clinical data. Phys Med Biol 2008;53:737-55.

139. Schilstra $C$, Meertens $H$. Calculation of the uncertainty in complication probability for various dose-response models, applied to the parotid gland. Int J Radiat Oncol Biol Phys 2001;50:147-58. 